\title{
Detrimental pro-senescence effects of vitamin D on lung fibrosis
}

\author{
Trinidad Guijarro ${ }^{1 \dagger}$, Esmeralda Magro-Lopez ${ }^{1 \dagger}$, Joana Manso', Ricardo Garcia-Martinez², \\ Maria Jesus Fernandez-Aceñero ${ }^{2}$, Isabel Liste ${ }^{1}$ and Alberto Zambrano ${ }^{1 *}$ (i)
}

\begin{abstract}
Background: The multiple biological effects of vitamin D and its novel activities on inflammation and redox homeostasis have raised high expectations on its use as a therapeutic agent for multiple fibrogenic conditions. We have assessed the therapeutic effects of 1a,25-Dihydroxyvitamin $D_{3}$, the biologically active form of vitamin $D$, in the context of lung fibrosis.

Methods: We have used representative cellular models for alveolar type II cells and human myofibroblasts. The extension of DNA damage and cellular senescence have been assessed by immunofluorescence, western-blot and senescence-associated $\beta$-galactosidase activity. We have also set up a murine model for lung fibrosis by intraperitoneal injections of bleomycin.

Results: Vitamin D induces cellular senescence in bleomycin-treated alveolar epithelial type II cells and aggravates the lung pathology induced by bleomycin. These effects are probably due to an alteration of the cellular DNA doublestrand breaks repair in bleomycin-treated cells.
\end{abstract}

Conclusions: The detrimental effects of vitamin D in the presence of a DNA damaging agent might preclude its use as an antifibrogenic agent for pulmonary fibrosis characterized by DNA damage occurrence and cellular senescence.

\section{Introduction}

Vitamin D is a hydrophobic secosteroid involved in the homeostasis of calcium, magnesium, iron, phosphate and zinc. The biological form of vitamin D $\left(1 \alpha, 25\right.$-Dihydroxyvitamin $\mathrm{D}_{3}$, from now on vitamin $\left.\mathrm{D}\right)$ exerts its activity through the binding to the vitamin $\mathrm{D}$ receptor (VDR), a member of the nuclear hormone receptor superfamily (Pike and Christakos 2017). Besides its role on mineral metabolism, vitamin $\mathrm{D}$ regulates some chronic conditions including autoimmune, cardiovascular and respiratory diseases (Finklea et al. 2011). Vitamin D and its analogs are also active in the regulation of fibrosis that characterizes multiple chronic diseases such as renal, cardiac, liver or pulmonary fibrosis (Ding et al. 2013; Ito et al. 2013; Meredith et al. 2015; Zhang et al. 2015). Regarding the

\footnotetext{
* Correspondence: azambra@isciii.es

†Trinidad Guijarro and Esmeralda Magro-Lopez contributed equally to this work.

${ }^{1}$ Functional Unit for Research into Chronic Diseases, Institute of Health Carlos III, Ctra. Majadahonda-Pozuelo Km 2, 28220 Madrid, Spain

Full list of author information is available at the end of the article
}

latter condition a preventive treatment with vitamin D supplementation ameliorated the severity of lung fibrosis probably due to its anti-inflammatory effects. However, the "therapeutic" role of vitamin D supplementation has not so far been assessed in the context of lung fibrosis. Idiopathic pulmonary fibrosis (IPF) is a form of progressive interstitial pneumonia of unknown etiology (King Jr. et al. 2011). IPF is an example of aging with median diagnosis at 66 years and estimated survival of 3-4 years. In essence, IPF pathogenesis is the consequence of an excessive matrix deposition leading to tissue scarring and irreversible organ injury probably due to a persistent input of damage and tissue repair response. A cellular state called senescence is implicated in the tissue repair program and in IPF physiopathology. Essentially, cellular senescence is an irreversible state of proliferation induced by multiple stressors such as oxidative stress, DNA damage, protein instability and telomere attrition. Its primary role is to make the cell damage inflicted visible for the immune system in order to draw the elimination of damaged cells. Multiple 
senescence biomarkers accumulate in both fibroblasts and epithelial cells in IPF lungs including the expression of CDKN1A (p21), CDKN2A (p16), senescenceassociated $\beta$-galactosidase activity (SA- $\beta$ gal) and DNA damage (Kuwano et al. 1996; Schafer et al. 2017). The occurrence of cellular senescence in IPF, in contrast to other fibrogenic conditions, has a detrimental role in the progression of the disease (Hecker et al. 2014; Lv et al. 2013; Shivshankar et al. 2012).

A number of evidences support the hypothesis that epithelial injury and impaired regeneration are sufficient to activate fibroblasts in the context of IPF. It has been proposed that cellular senescence induced by persistent epithelial damage may be the origin of such defective regeneration and the promotion of fibrosis. Indeed, accelerated epithelial senescence seems to play a role in the development of IPF (Aoshiba et al. 2013; Aoshiba et al. 2003; Chilosi et al. 2013; Kuwano et al. 2016). By other hand, vitamin D treatment or vitamin D receptor (VDR) have been implicated in the attenuation of fibrosis of various organs (Ding et al. 2013; Ito et al. 2013; Meredith et al. 2015; Zhang et al. 2015). Less is known, however, about its role in lung fibrosis. Some previous reports indicated that supplementation of vitamin D ameliorated the fibrotic effects induced by bleomycin (Zhang et al. 2015; Tan et al. 2016; Zhang et al. 2013). The common fact to these works is the preventive administration of vitamin D that, very probably, mediated these effects through its well-known anti-inflammatory properties.

We have evaluated the effects of the biological active form of vitamin $\mathrm{D}, 1 \alpha, 25$-Dihydroxyvitamin $\mathrm{D}_{3}$ or calcitriol, in two in vitro models for human alveolar type II (ATII) cells and myofibroblasts in terms of DNA damage, cellular senescence and fibrogenic activation. In addition, we have set up an IPF model consisting of the systemic exposure of mice to the antibiotic bleomycin in order to assess the potential "therapeutic" effect of vitamin D. The results indicate that only in the presence of the DNA damaging agent (bleomycin) vitamin $\mathrm{D}$ induces an alteration in the correct repair of DNA double-strand breaks (DSBs) and the induction of cellular senescence in epithelial cells. In our model of myofibroblasts, however, the response to bleomycin is the fibrogenic activation rather than their commitment to a senescence state. Moreover, our in vivo results indicate that rather than inhibiting lung fibrosis the treatment with vitamin D aggravates the disease probably due to the excessive presence of DNA damage in the form of DSBs especially in epithelial cells. Altogether our results suggest a detrimental role of vitamin $D$ supplementation in lung fibrosis thus precluding its use as an antifibrogenic agent for IPF.

\section{Materials and methods}

\section{Cell culture}

Alveolar epithelial cells type II (A549, ATCC) and human myofibroblasts (Magro-Lopez et al. 2017) (Abyntek Biopharma) were maintained in DMEM medium supplemented with 10\% FBS (Sigma), $2 \mathrm{mM}$ glutamine and $100 \mathrm{U} / \mathrm{mL}$ of penicillin and streptomycin (Lonza). We used the active form of vitamin D $(1 \alpha, 25$-Dihydroxyvitamin $\mathrm{D}_{3}$ or calcitriol; Sigma-Aldrich (cat.\#D1530). Vitamin D stock was $10 \mu \mathrm{M}$ in ethanol. Treatments were performed in cells maintained in DMEM supplemented with $10 \%$ hormone-depleted serum. This serum was prepared by using the anion exchange resin $\mathrm{AG}^{\mathrm{R}} 1-\mathrm{X} 8$ from BIO-RAD (cat.\#1401441) as previously described (Zambrano et al. 2014). Bleomycin sulfate (cat.\# CAYM13877-50) was purchased to VWR.

\section{Analysis of proteins by western-blot}

Cell monolayers were washed with ice-cold PBS and lysed in triple-detergent lysis buffer $[50 \mathrm{mM}$ Tris- $\mathrm{HCl}$ $\mathrm{pH}$ 8.0, $150 \mathrm{mM} \mathrm{NaCl}, 0.02 \%$ sodium azide, $0.1 \%$ SDS, $1 \%$ NP-40, $0.5 \%$ sodium deoxycholate, $100 \mu \mathrm{g} / \mathrm{ml}$ PMSF, $2 \mu \mathrm{g} / \mathrm{ml}$ pepstatin, $2 \mu \mathrm{g} / \mathrm{ml}$ aprotinin, $2 \mu \mathrm{g} / \mathrm{ml}$ leupeptin, and phosphatase inhibitors cocktail 2 or 3 (cat.\#P5726, P0044, Sigma-Aldrich)]. SDS-PAGE and immunoblotting were performed under standard conditions. Basically, samples in Laemmli buffer ( $30 \mu \mathrm{g} / \mathrm{lane})$ were separated through $8 \%$ or $12 \%$ gels and transferred to nitrocellulose membranes for $90 \mathrm{~min}$ at RT in the presence of $20 \%$ methanol and 0,1\% SDS. Membranes were blocked with 3\% BSA in PBS-Tween 0,05\% (PBST-BSA) and incubated $\mathrm{O} / \mathrm{N}$ at $4{ }^{\circ} \mathrm{C}$ with specific antibodies diluted in PBST-BSA. Antibodies used were: $\gamma \mathrm{H} 2 \mathrm{AFX}$ (cat.\#05-636, Millipore), CDKN1A (cat.\#sc-6246, Santa Cruz Biotech), CDKN2A (cat.\#04-239, Millipore), Cdkn2a (Millipore, cat.\#PA5-20379), ACTA2 (cat.\#MA5-11547, Thermoscientific), VIMENTIN (cat.\#MA1-10459, Thermoscientific), Vitamin D receptor (VDR) (cat.\#12550S, Cell Signaling), Tata box-binding protein (TBP) (cat.\#818, abcam), tubulin (TUBA1A) (cat.\#T9026, Sigma-Aldrich) and actin $\beta$ (ACTB) (cat.\#8224, abcam).

\section{Quantitative real-time RT-PCR (RT-qPCR)}

RNA extraction and RT reactions were performed with Trizol reagent (cat.\#15,596,026; Ambion) and the high-capacity cDNA kit (cat.\#4,387,406; Applied Biosystems) following the manufacturer's instructions. Real-time PCR was performed by using the powerUp SYBR Green mix (cat.\#A25742) and the Quantstudio-3 system from Applied Biosystems. The relative amounts of the amplification products were calculated by the $\Delta \Delta \mathrm{Ct}$ method. The genes analyzed, and the sequences of the oligonucleotides employed in this study were the following: 


\begin{tabular}{|c|c|}
\hline rRNA $18 \mathrm{~S}$ & $\begin{array}{l}\text { 5'-GTAACCCGTTGAACCCCATT } \\
\text { 5'-GCCTGCTTCAACCACCTTC } \\
\text { TTG }\end{array}$ \\
\hline GAPDH & $\begin{array}{l}\text { 5'-ACAGTCCATGCCATCACTGCC } \\
\text { 5'-CCATCCAATCGGTAGTAGCC }\end{array}$ \\
\hline COLA1A (Collagen type I) & $\begin{array}{l}\text { 5'-CAGCCGCTTCACCTACAGC } \\
\text { 5'-TITGTATTCAATCACTGT } \\
\text { CTTGCC }\end{array}$ \\
\hline COLA3A (Collagen type III) & $\begin{array}{l}\text { 5'- ATGGTTGCACGAAACACACT } \\
\text { 5'- CTTGATCAGGACCACCAATG }\end{array}$ \\
\hline $\begin{array}{l}\text { ACTA2 (a-smooth muscle actin, } \\
\text { a-SMA) }\end{array}$ & $\begin{array}{l}\text { 5'- CCGACCGAATGCAGAAGGA } \\
\text { 5'- ACAGAGTATTTGCGCTCCG } \\
\text { AA }\end{array}$ \\
\hline TGFB1 & $\begin{array}{l}\text { 5'-TGGCGATACCTCAGCAC } \\
\text { 5'-CTCGTGGATCCACTTCCAG }\end{array}$ \\
\hline CYP24A1 & $\begin{array}{l}\text { 5'-GGTGACATCTACGGCGTAC } \\
\text { 5'-CTTGAGACCCCCTITCCAGAG }\end{array}$ \\
\hline Cyp24a1 & $\begin{array}{l}\text { 5'-CTGCCCCATTGACAAAAGGC } \\
\text { 5'-CTAACCGTCGGGTCATCAGC }\end{array}$ \\
\hline
\end{tabular}

\section{ROS analysis}

Reactive oxygen species were detected with the probes DA-DCFH (D6883, Sigma-Aldrich) and MitoSOX (M36008, Invitrogen) by flow-cytometry.

ROS detection by 2'-7'-dichlorofluorescein diacetate (DA-DCFH) Cells growing in DMEM supplemented with 10\% hormone-depleted serum were seeded at a density of 32,000 cells $/ \mathrm{cm}^{2}$ in MW12 plates. At the following day the medium was replaced by fresh medium and the cells were pre-treated for $2 \mathrm{~h}$ with $5 \mathrm{nmol} / \mathrm{L}$ vitamin $\mathrm{D}$ (1 $\alpha, 25$-Dihydroxyvitamin $\mathrm{D}_{3}$ ) and then treated for $24 \mathrm{~h}$ with bleomycin $(12,5 \mu \mathrm{g} / \mathrm{mL})$ and/or $5 \mathrm{nmol} / \mathrm{L}$ vitamin D. The cultures were then washed twice with Hank's balanced salt solution (HBSS) and incubated for $1 \mathrm{~h}$ with HBSS. After that, the cells were incubated with DA-DCFH $(20 \mu \mathrm{M})$ in HBSS for $1 \mathrm{~h}$, washed and trypsinized. Trypsin was neutralized with HBSS-FBS $2 \%$ and the cells were collected and analyzed immediately by flow cytometry. The measurements were carried out using FACSCanto (BD Bioscience) cytometer. Cell debris as represented by distinct low forward and side scatter were gated out for analysis; 25,000 gated events for each condition were analyzed with the FACSCanto and Flow Jo software.

\section{Detection of mitochondrial ROS by MitoSOX}

The treatments were carried-out as for the DA-DCFH probe. Cells were incubated for $1 \mathrm{~h}$ with $5 \mu \mathrm{M}$ MitoSOX in HBSS and then processed for flow cytometry.

The controls for ROS induction employed in these experiments consisted of treatments for $1 \mathrm{~h}$ with $50 \mu \mathrm{M}$ terbutyl hydroperoxide (cat.\#416,665, Sigma-aldrich).
Senescence-associated $\beta$-galactosidase assay (SA- $\beta$ gal)

SA- $\beta$ gal assays were performed as previously described by (Dimri et al. 1995). Micrographs were taken in a microscope TS100F (Nikon) equipped with a digital camera DS-L1 (Nikon).

\section{Indirect immunofluorescence}

Cells were seeded in 8-well chambers (cat.\#154,534; Thermofisher Scientific) at a density of 20,000 cells/well. The following day the cells were treated as indicated in the corresponding experiments. Immunofluorescence was performed as previously described (Zambrano et al. 2014). Basically, cells were fixed in 2\% PFA in PBS for 10 min at RT and permeabilised with $0.1 \%$ Triton X-100 and 0.1\% sodium citrate $(5 \mathrm{~min} / \mathrm{RT})$. Preparations were then washed with PBS and washing solution (PBS/0.25\% BSA/0.1\% Tween 20), blocked for $30 \mathrm{~min}$ with blocking solution (washing solution $+2.5 \% \mathrm{BSA}$ ), and incubated overnight with antibodies against TP53BP1 (NB-100-304, Novus Biologicals), PTK2 (focal adhesion kinase FAK; cat.\#PA516676 Thermosicentific), ACTA2 ( $\alpha$-SMA; cat.\#MA511547, Thermoscientific). Preparations were then washed with washing solution and incubated with secondary antibodies conjugated with alexa fluor dyes $(488,546)$ from Life Technologies (cat.\#A-11029, cat.\#A-11035) for $1 \mathrm{~h}$ at RT. Nuclei were counterstained with DAPI, and samples were mounted with ProLong Diamond (cat.\#P36961; Life Technologies). Cell images were captured with a fluorescence microscopy (Zeiss Axio) equipped with a camera (Axiocam MRm) and AxioVision software. DNA damage foci were counted from $>150$ cells for each experimental condition.

\section{Chromatin immunoprecipitation (ChIP) assays}

Cells growing in DMEM supplemented with 10\% hormone-depleted serum, were seeded in $150-\mathrm{mm}$ dishes $\left(6 \times 10^{6}\right.$ cells/plate $)$ and the next day pretreated with $5 \mathrm{nmol} / \mathrm{L}$ of vitamin $\mathrm{D}(1 \alpha, 25$-Dihydroxyvitamin $\mathrm{D}_{3}$ ) for $2 \mathrm{~h}$. Cells were then treated with bleomycin $(12,5 \mu \mathrm{g} / \mathrm{mL})$ for $6 \mathrm{~h}$, washed and incubated in the presence or absence of $5 \mathrm{nmol} / \mathrm{L}$ vitamin D. After $48 \mathrm{~h}$, cells were washed, and lysed following specifications of the magnetic-bead based ChIP Assay Kit (17-10,085, EMD Millipore), and sonicated in a Bioruptor (UCD-200TM; Diagenode). Immunoprecipitated DNA was purified with the QIAquick PCR purification kit (cat.\#28,106, Qiagen). In each immunoprecipitation, $2-3 \times 10^{6}$ cells and $1 \mu \mathrm{g}$ of the following antibodies: normal IgGs (cat.\#sc-2027, sc-2025, Santa Cruz Biotech.), Histone H3 (cat.\#ab1791; abcam), Acetylated Histone H3 (cat.\#06-599; Upstate) and H3K27-3me (cat.\#ab 6002; abcam) were used. DNA was amplified with primers P16(-277): 5'-GTCCCTGCC CCTTTGCTATT and P16(+ 95): 5'-ACGGGTCGG GTGAGAGTC, that amplify a region encompassing the 
proximal P16 promoter (P16 ${ }^{\mathrm{INK} 4 \mathrm{a}}$ promoter) at the human $C D K N 2 A$ locus. Real-time PCR was performed by using the powerUp SYBR Green mix and the Quantstudio-3 system from Applied Biosystems. The analysis was performed by the percentage input method (Haring et al. 2007).

\section{Mice, bleomycin-based model of lung fibrosis and immunohistochemistry}

Lung fibrosis was induced in pathogen-free 8- to 10-wk-old (weight 18-22 g) female C57BL/6 J mice by two intraperitoneal (i.p.) injections of bleomycin, diluted in $0,9 \%$ saline $(0,1 \mathrm{mg} / \mathrm{Kg}$ b.w.), at days 0 and 2 . At day 11 , after the acute inflammatory response, the treatments with vitamin $\mathrm{D}\left(1 \alpha, 25\right.$-Dihydroxyvitamin $\left.\mathrm{D}_{3}\right)$ or vehicle were initiated ( $5 \mathrm{ng} / \mathrm{g}$ b.w.). The doses employed and the protocol consisting of various i.p. injections have previously been described (Tan et al. 2016; Lee et al. 2015; Wang et al. 2016; Schapochnik et al. 2018). $1 \alpha, 25$-Dihydroxyvitamin $\mathrm{D}_{3}$ or the equivalent volume of vehicle was dissolved in saline immediately before the injections. Mice received an injection on days 11, 14, 17, 21 and 24 and were killed at day 28 . The mice were divided randomly into the following experimental groups (five mice per group): a) saline only, b) bleomycin, c) bleomycin + vehicle and d) bleomycin + vitamin $\mathrm{D}(1 \alpha$, 25-Dihydroxyvitamin $D_{3}$ ). These experiments were repeated three times and were approved by the Committee of Bioethics and Animal Welfare of the Instituto de Salud Carlos III and Community of Madrid (file reference: PROEX-312). Protocols used followed the guidelines for animal protection reported by the Spanish national law RD 53/2013.

\section{Histology}

Lungs and liver were removed from each animal, dissected and fixed in $4 \%$ buffered formalin and embedded in paraffin wax or flash frozen with OCT compound. Four-micrometer sections from paraffin embedded tissue were stained with hematoxylin and eosin for assessment of tissue morphology or with trichrome to identify collagen.

\section{Immunohistochemistry}

Immunohistochemistry was performed on $4 \mu$-sections of paraffin-fixed embedded tissue. Antigen retrieval was performed with citrate buffer ( $\mathrm{pH} 6)$ using a Microwave Tender Cooker (Nordic Ware) and a $700 \mathrm{~W}$ microwave $(15 \mathrm{~min} 700 \mathrm{~W} / 15 \mathrm{~min} 350 \mathrm{~W})$. Endogenous peroxidase activity was inhibited with $0.3 \% \mathrm{H}_{2} \mathrm{O}_{2}$ in methanol (25 $\mathrm{min}$ ) and after that the sections were permeabilized and blocked simultaneously with PBS $+1 \% \mathrm{BSA}+0,1 \%$ TX-100, during $30 \mathrm{~min}$. The slides were then washed once with PBS for $5 \mathrm{~min}$. Endogenous biotin, biotin receptors and avidin binding sites were blocked by using the avidin/biotin blocking kit from Vector Laboratories (cat.\#SP-2001). The slides were washed with PBS and incubated $\mathrm{ON}$, in a humidity chamber, with the primary antibody diluted in blocking solution (PBS $+1 \% \mathrm{BSA}$ ). Incubations with the secondary biotinylated antibodies and development were performed with the kits MP-7402 (ImmPRESS) and SK-4605 (ImmPACT VIP HRP substrate) from Vector Laboratories, following their instructions. Methyl green (cat.\#M8884-5G; Sigma-Aldrich) was used as counterstaining and xylene substitute mountant (cat.\#1,900,231; Thermofisher) as mounting medium. Primary antibody used was $\gamma \mathrm{H} 2 \mathrm{AFX}$ (1:1000, cat.\#05-636 Millipore). Damaged cells were counted from representative immunohistochemical fields for each experimental condition.

\section{Statistical analysis}

Statistical significance of data was determined by applying a two-tailed Student's t test or the analysis of variance followed by the Newman-Keuls or Bonferroni post-tests for the experiments with more than two experimental groups. $P<0.05$ is considered significant. Significance of the analysis of variance post-test or the Student's $\mathrm{t}$ test is indicated in the figures as ", $P<0.05$; $\because *, P<0.01$; and $* * *, P<0.001$. Statistics were calculated with the Prism 7 software (GraphPad Software). Data were subjected to the Shapiro-Wilk test and D'Agostino and Pearson omnibus test to verify their normality. The results presented in the figures are means \pm SEM. Experiments were repeated at least two times.

\section{Results}

Effects of vitamin D and bleomycin in A549 cells and human lung fibroblasts

Effects of vitamin D in A549 cells [alveolar type II cells (ATII)]

A549 cells express the VDR, which is overexpressed in the presence of $1 \alpha, 25$-Dihydroxyvitamin $\mathrm{D}_{3}$, vitamin $\mathrm{D}$ from now on (Fig. 1a). The treatment with $5 \mathrm{nmol} / \mathrm{L}$ vitamin $\mathrm{D}$ also increased the expression of vitamin $\mathrm{D}$ 24-hydroxylase (CYP24A1), a VDR target gene, indicating the VDR functionality in these cells (Fig. 1b). The treatment of A549 cells with $25 \mu \mathrm{g} / \mathrm{mL}$ of bleomycin for $48 \mathrm{~h}$ induced a drastic expression of DNA damage (DD) foci containing TP53BP1, a reliable marker of DNA double-strand breaks (DSBs) (Zambrano et al. 2014) (Fig. 1c). Under these conditions damaged cells ( 100\%) showed high densities of DD foci that precluded a reliable quantification of DD foci per nuclei however, the exposure of cells to a bleomycin shock $(12 \mu \mathrm{g} / \mathrm{mL}$ for 6 h), allowed us to quantify the number of DD foci per nucleus after 2 and 5 days post-shock (Fig. 1d-f). At 2 days post-shock the percentage of damaged cells was similar in all three groups of bleomycin treated cells however, after 5 days post-shock, cells treated with vitamin D 
A

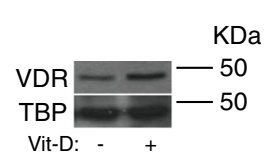

B

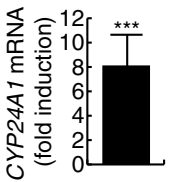

C

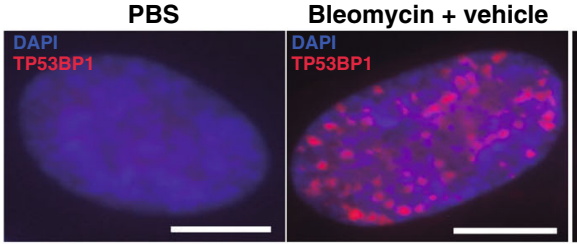

D

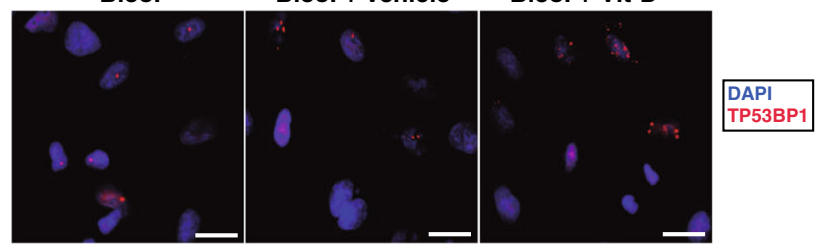

Bleomycin + Vit-D
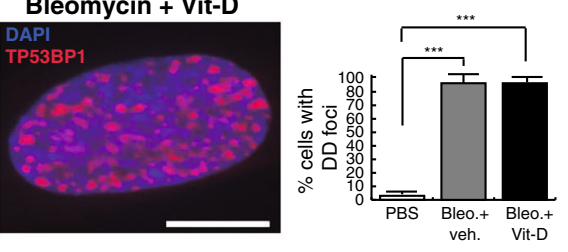

BP1

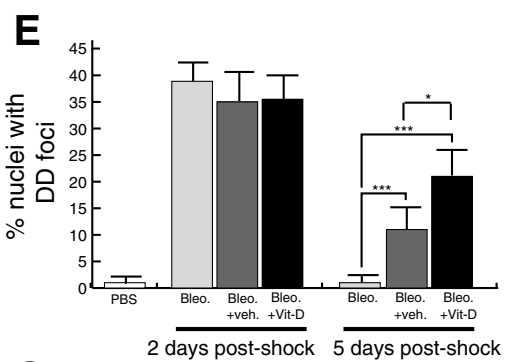

F $\quad 6$ Bleo. shock $12 \mu \mathrm{g} / \mathrm{mL}$

6h Bleo. shock $12 \mu \mathrm{g} / \mathrm{mL}$ analysis: 2 days post-shock analysis: 5 days post-shock
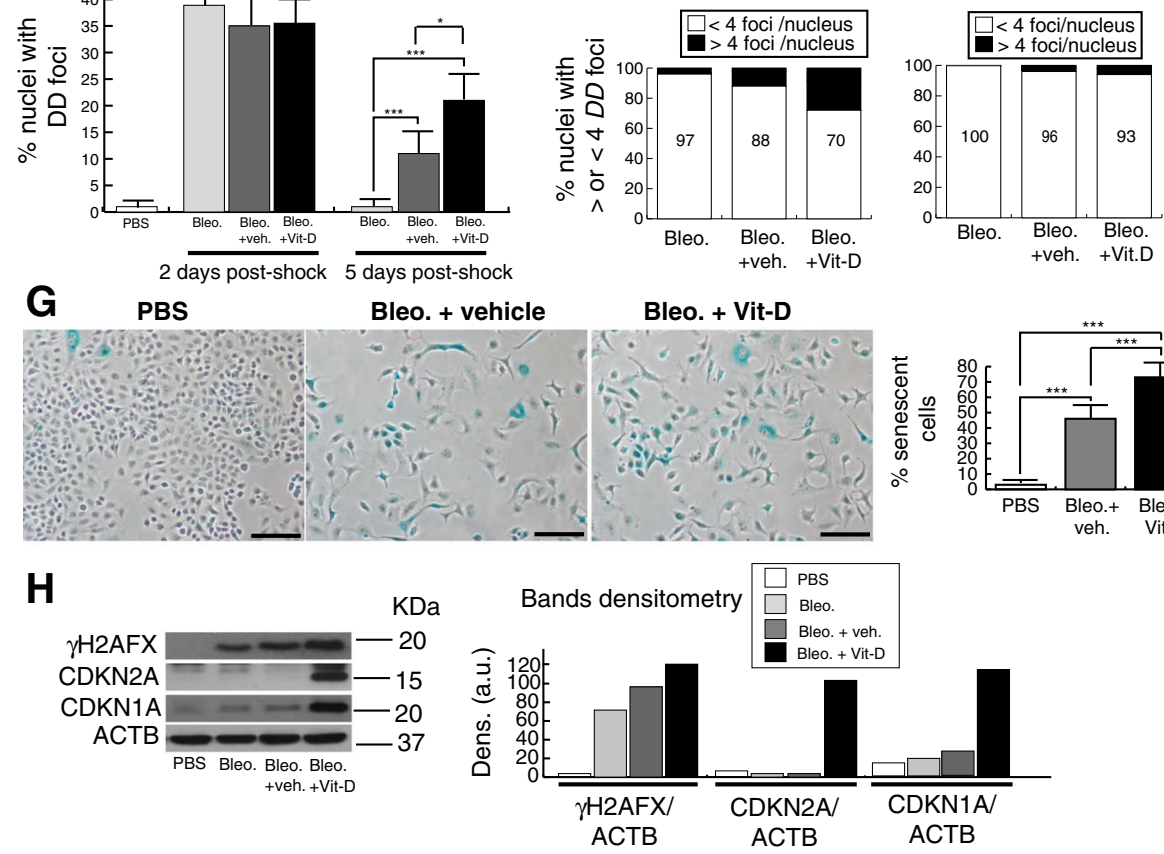

Fig. 1 Effects of vitamin D and bleomycin in A549 cells. a Detection of vitamin D receptor (VDR) in A549 cell extracts. Cells were treated or not with $5 \mathrm{nmol} / \mathrm{L}$ vitamin D for $48 \mathrm{~h}$. TBP (Tata box binding protein was used as loading control. KDa: kilodaltons. b RT-qPCR result: expression of CYP24A 1 in A549 cells treated for $48 \mathrm{~h}$ with $5 \mathrm{nmol} / \mathrm{L}$ vitamin D. Values are relative to A549 cells treated with vehicle. $\mathbf{c}$ Expression of DSBs induced by bleomycin. Representative micrographs of A549 nuclei harboring DNA damage foci containing TP53BP1, a marker of DSBs, are shown. Right panel: quantification of damaged cells. Scale bar: $5 \mu \mathrm{m}$. d Expression of TP53BP1 foci (red dots) in cultures of A549 cells pretreated with 5 $\mathrm{nmol} / \mathrm{L}$ vitamin $\mathrm{D}$ for $2 \mathrm{~h}$, subjected to a bleomycin shock $(12 \mu \mathrm{g} / \mathrm{mL}$ for $6 \mathrm{~h}$ ) and then treated with $5 \mathrm{nmol} / \mathrm{L}$ vitamin $D$ or its vehicle. Representative micrographs taken at $48 \mathrm{~h}$ post-shock are shown. Scale bar: $20 \mu \mathrm{m}$. e Quantification of damaged cells (nuclei with TP53BP1 foci) at two and five days after bleomycin shock $(12 \mu \mathrm{g} / \mathrm{mL}$ for $6 \mathrm{~h})$. $\mathbf{f}$ Quantification of DD foci per nucleus at two and five days after bleomycin shock $(12 \mathrm{\mu g} / \mathrm{mL}$ for $6 \mathrm{~h}) . \mathbf{g}$ Senescence-associated $\beta$-galactosidase assay (SA- $\beta$ gal). Representative micrographs of A549 cultures at $48 \mathrm{~h}$ post-treatments are shown. Scale bar: $100 \mu \mathrm{m}$. Quantification of senescent cells is shown in the right panel. $\mathbf{h}$ Detection of $\mathrm{YH} 2 \mathrm{AFX}, \mathrm{CDKN} 2 \mathrm{~A}$ and CDKN1A in A549 cell extracts. Cells were pretreated with $5 \mathrm{nmol} / \mathrm{L}$ vitamin $\mathrm{D}$ for $2 \mathrm{~h}$, subjected to a bleomycin shock $(12 \mu \mathrm{g} / \mathrm{mL}$ for $6 \mathrm{~h})$ and then treated with 5 $\mathrm{nmol} / \mathrm{L}$ vitamin D or its vehicle. Cell extracts were obtained at $48 \mathrm{~h}$ post-shock. Control cultures were cells treated with bleomycin vehicle (PBS). ACTB was used as loading control. KDa: kilodaltons. Right panel: densitometry analysis of bands; a.u: arbitrary units 
showed the highest levels of DNA damage (Fig. 1e). With regard to the amount of DD foci per nucleus, it was significantly higher in cells treated with both bleomycin and vitamin $\mathrm{D}$ compared to controls, at 2 days post-shock (Fig. 1f). At 5 days post-shock however, the majority of the cells exhibited $<4$ foci per nucleus as a consequence of the cellular DNA repair activity (right panel, Fig. 1f).

As DNA damage is behind the onset of cellular senescence we evaluated the $\beta$-galactosidase activity (SA-Bgal) in cultures treated for $48 \mathrm{~h}$ with $25 \mu \mathrm{g} / \mathrm{mL}$ of bleomycin. We consistently found significant higher levels of cellular senescence in cells treated with bleomycin and vitamin D compared to controls (Fig. 1g). The treatment of A549 with vitamin D in the absence of the damaging agent did not increase the low basal levels of DNA damage and senescence. Consistent with this, the continuous exposure of A549 cells to vitamin D during three consecutive passages did not alter their replication rates (Fig. 2a). The occurrence of cellular senescence was also evaluated by western-blot. Consistent with the increase in the levels of SA- $\beta$ gal activity, we found higher expression levels of DNA damage and cellular senescence markers $(\gamma \mathrm{H} 2 \mathrm{AFX}, \mathrm{CDKN} 1 \mathrm{~A}$ and CDKN2A) in cultures treated with bleomycin and vitamin D compared to controls (Fig. 1h).

\section{Effects of vitamin $D$ in human lung myofibroblasts}

We also evaluated the effects of vitamin D in terms of DNA damage and fibrogenic activation in human lung myofibroblasts previously characterized (Magro-Lopez et al. 2017). These fibroblasts exhibit the typical spindle-shaped myofibroblasts morphology and can accumulate $\sim 2-3$ population-doubling levels (PDLs) per passage for at least 10 consecutive passages, consistent with the absence of replicative senescence (Fig. 3a, b). As for the
A

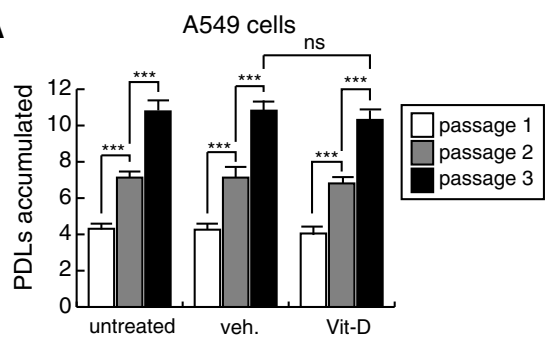

B

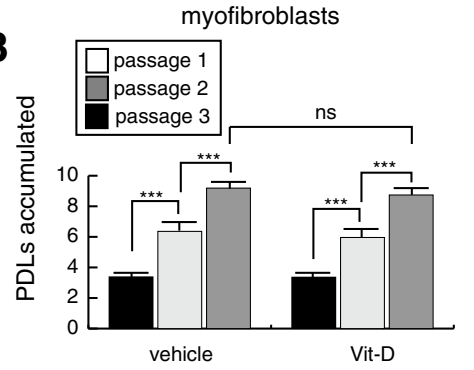

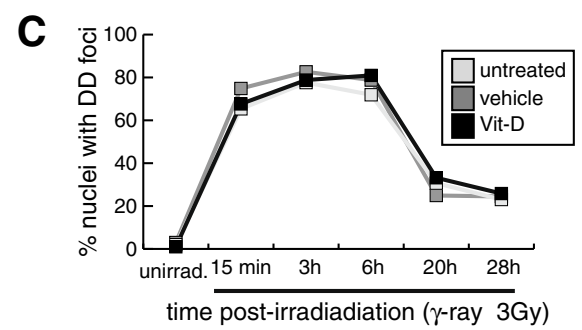

$28 \mathrm{~h}$ post-irradiation

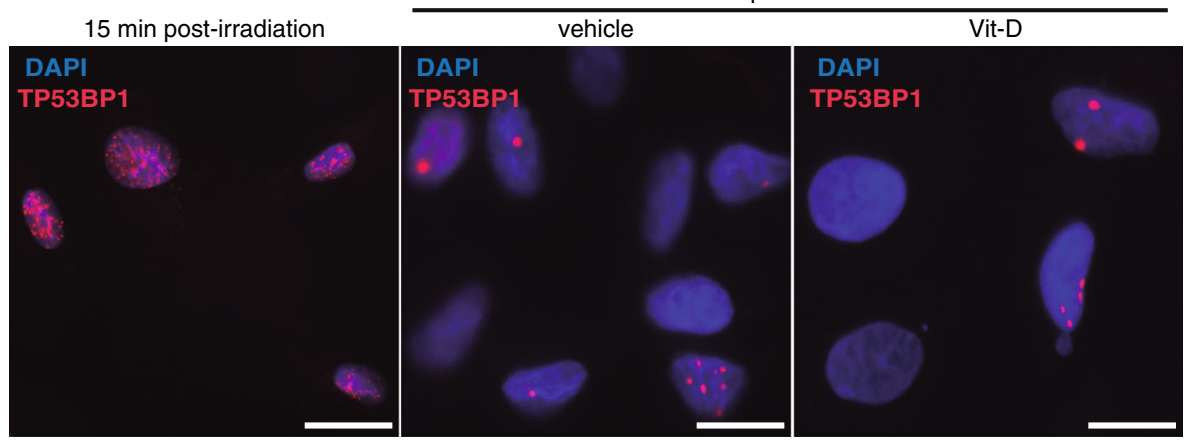

Fig. 2 Results related to serial cell passages and $y$-ray radiations. a Accumulation of population doubling levels during three passages of A549 cells treated with $5 \mathrm{nmol} / \mathrm{L}$ vitamin D or its vehicle. $\mathbf{b}$ Accumulation of population doubling levels during three passages of myofibroblasts treated with $5 \mathrm{nmol} / \mathrm{L}$ vitamin D or its vehicle. c Kinetics of DNA repair of DSBs induced by $\gamma$-radiation (3Gy). A549 cells were treated with $5 \mathrm{nmol} /$ $\mathrm{L}$ vitamin $\mathrm{D}$ or its vehicle $2 \mathrm{~h}$ before irradiations and then subjected to $3 \mathrm{~Gy}$ of $\mathrm{\gamma}$-ray. At different times post-irradiation, cells were processed for indirect immunofluorescence of TP53BP1 to detect DSBs. DNA DD foci were quantified from representative micrographs (more than 150 cells examined). Bottom pictures show representative micrographs of the kinetics at 15 min and $28 \mathrm{~h}$ post-irradiation 


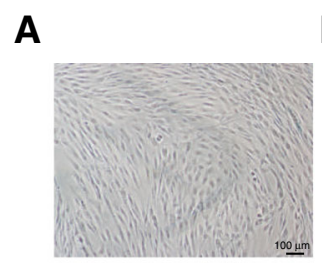

E
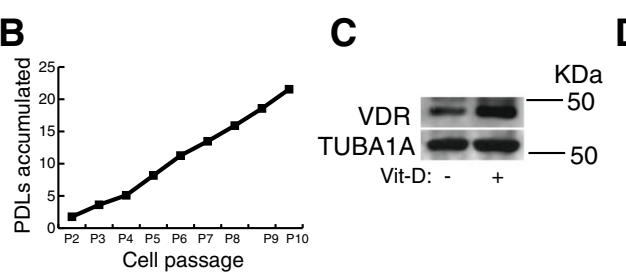

D
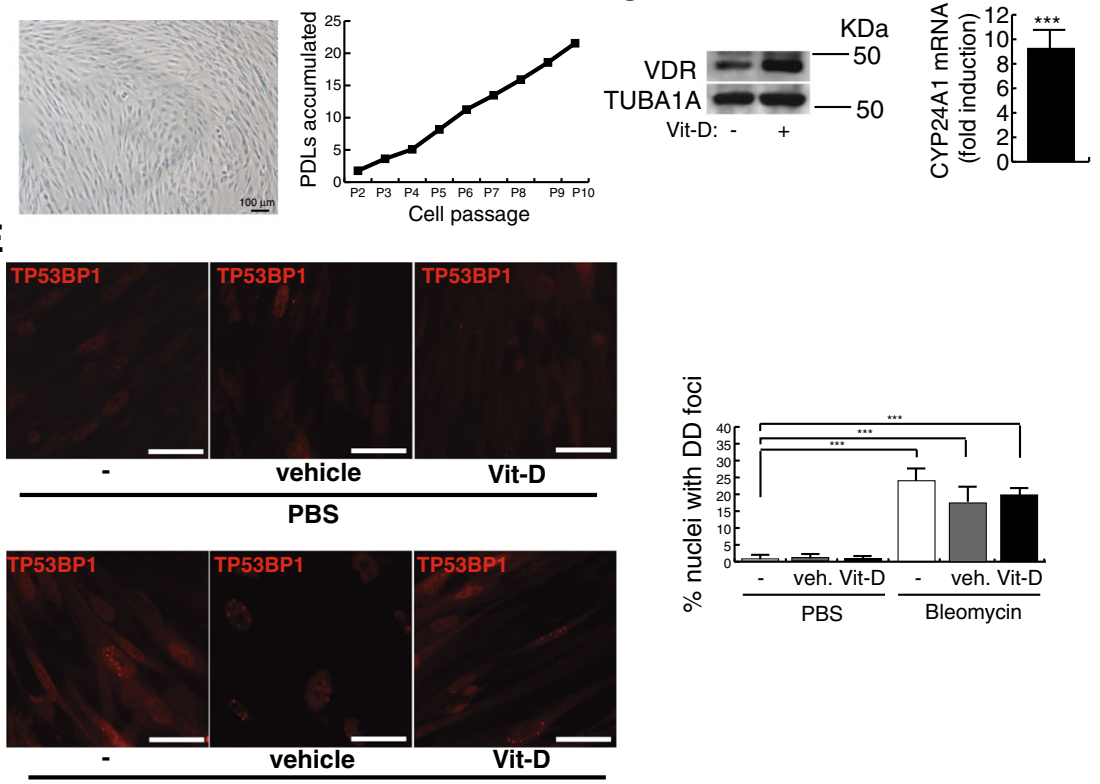

Bleomycin

$\mathbf{F}$

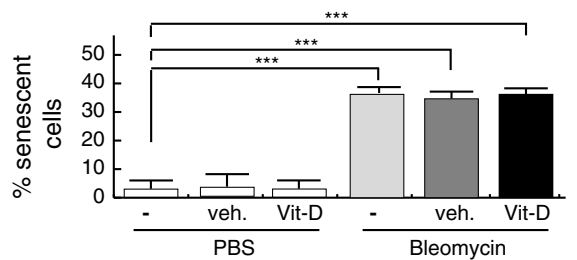

G

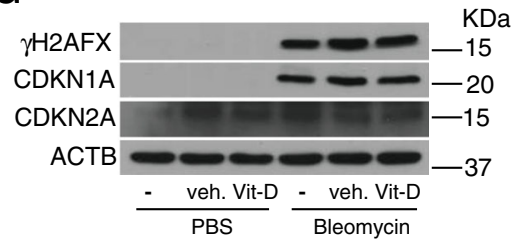

Fig. 3 Effects of vitamin D and bleomycin in human myofibroblasts. a Representative micrographs of a typical myofibroblasts culture. Scale bar: $100 \mu \mathrm{m}$. b Accumulation of population doubling levels (PDLs) during ten consecutive passages. c Detection of vitamin D receptor (VDR) in myofibroblasts extracts. TUBA1A (tubulin a was used as loading control. KDa: kilodaltons. d RT-qPCR result: expression of CYP24A1 in myofibroblasts cultures treated with $5 \mathrm{nmol} / \mathrm{L}$ vitamin D. Values are relative to cells treated with vehicle. e Expression of TP53BP1 foci (red dots) in cultures of myofibroblasts pretreated with $5 \mathrm{nmol} / \mathrm{L}$ vitamin $\mathrm{D}$ for $2 \mathrm{~h}$, subjected to a bleomycin shock $(12 \mu \mathrm{g} / \mathrm{mL}$ for $6 \mathrm{~h})$ and then treated with 5 $\mathrm{nmol} / \mathrm{L}$ vitamin D or its vehicle. Representative micrographs taken at $48 \mathrm{~h}$ post-shock are shown. Scale bar: $20 \mu \mathrm{m}$. Right panel: quantification of damaged cells (nuclei with TP53BP1 foci). f Quantification of the senescence levels (\% of SA- $\beta$ gal ${ }^{+}$cells). Myofibroblasts were pretreated with 5 $\mathrm{nmol} / \mathrm{L}$ vitamin $\mathrm{D}$ for $2 \mathrm{~h}$, subjected to a bleomycin shock $(12 \mu \mathrm{g} / \mathrm{mL}$ for $6 \mathrm{~h})$ and analyzed at $48 \mathrm{~h}$ post-shock. PBS is the bleomycin vehicle; veh.: vitamin D vehicle. $\mathbf{g}$ Detection of $\mathrm{YH} 2 \mathrm{AFX}, \mathrm{CDKN} 2 \mathrm{~A}$ and CDKN1A in myofibroblasts cell extracts. Cells were pretreated with $5 \mathrm{nmol} / \mathrm{L}$ vitamin D for $2 \mathrm{~h}$, subjected to a bleomycin shock $(12 \mu \mathrm{g} / \mathrm{mL}$ for $6 \mathrm{~h}$ ) and then treated with $5 \mathrm{nmol} / \mathrm{L}$ vitamin $\mathrm{D}$ or its vehicle. PBS is the bleomycin vehicle; veh.: vitamin D vehicle. ACTB was used as loading control. KDa: kilodaltons

case of A549 cells, these myofibroblasts express constitutively the VDR that together with the target gene CYP24A1, can be overexpressed in the presence of $5 \mathrm{nmol} / \mathrm{L}$ vitamin D (Fig. 3c, d). We performed this type of experiments in fibroblasts cultures with less than five passages where the levels of DNA damage and senescence in the population are consistently negligible. The treatment with bleomycin of fibroblasts cultures under the two conditions tested (either a constitutive exposure or in the form of a shock) induced the expression of TP53BP1-expressing DD foci that could not be further increased in the presence of vitamin D. In Fig. 3e the results corresponding to $6 \mathrm{~h}$ bleomycin shock $(12 \mu \mathrm{g} / \mathrm{mL})$ are shown. Contrary to the A549 cells, the treatment with vitamin $\mathrm{D}$ did not give rise to an increase in the levels of senescence and DNA damage reached by the sole exposure to bleomycin (Fig. 3f, g). The treatment with bleomycin for 3 days induced the expression of TGFB1, collagen I and III (COL1A1, COL3A1) and $A C T A 2$ [ $\alpha$-smooth muscle actin $(\alpha-S M A)]$, a representative cluster of genes whose expression is associated to the fibrogenic activation (Fig. 4a). As expected, the exposure to vitamin D inhibited significatively the expression of those profibrogenic genes and of VIMENTIN (VIM) (Fig. 4a, b). This inhibitory effect could also be observed by indirect immunofluorescence of $\alpha$-smooth muscle actin fibers and the focal adhesion kinase (PTK2), reliable markers of the fibrogenic activation (Lagares et al. 2012) (Fig. 4c, d). In these cells, the exposure to bleomycin preferentially led to their fibrotic activation and, as previously described, vitamin D exhibited its antifibrogenic effects. In the absence of 

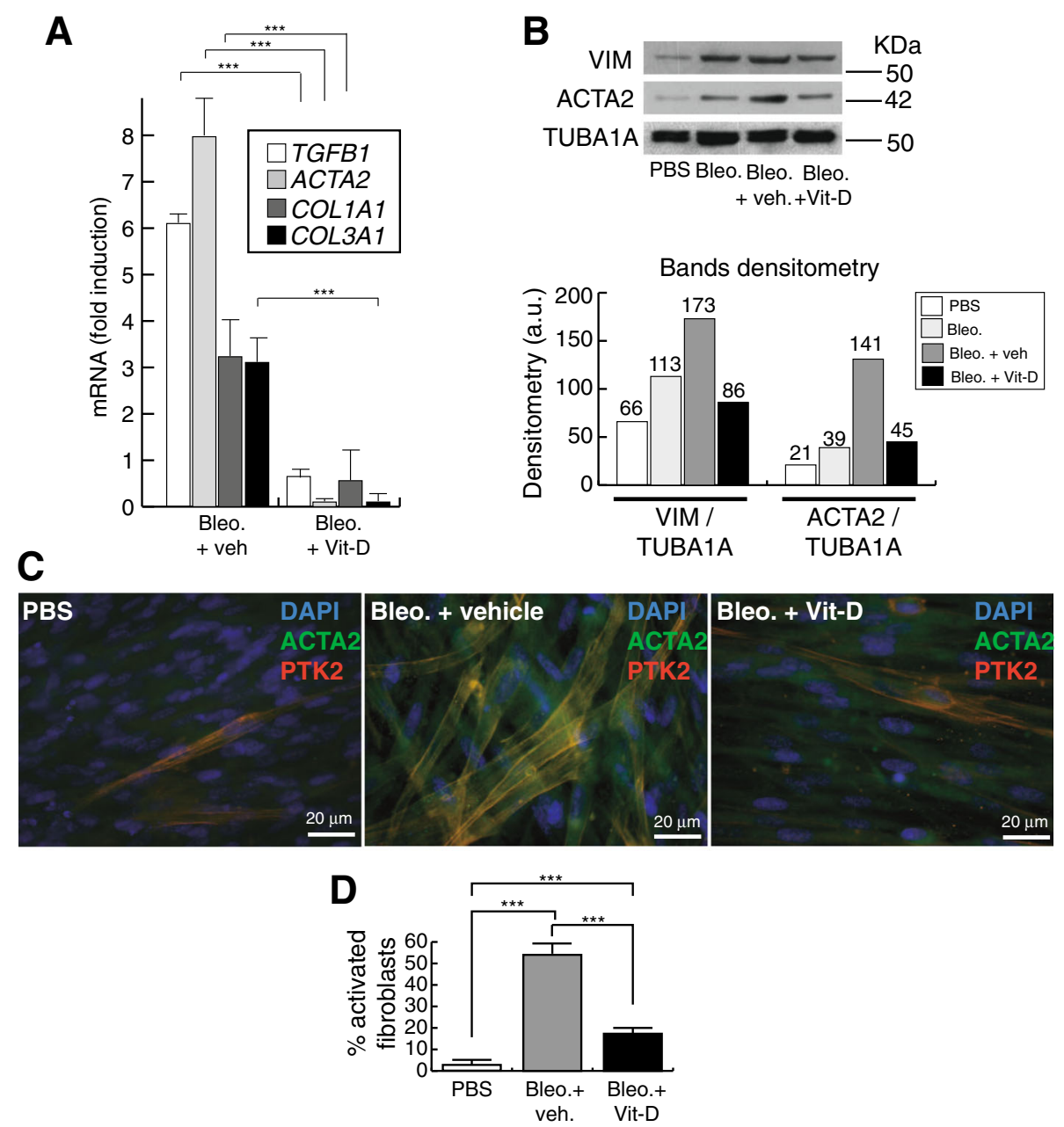

Fig. 4 Effect of vitamin D on the fibrogenic activation of myofibroblasts. a RT-qPCR result: expression of a representative profibrogenic cluster of genes. Cells were pretreated with $5 \mathrm{nmol} / \mathrm{L}$ vitamin $\mathrm{D}$ for $2 \mathrm{~h}$, subjected to a bleomycin shock $(12 \mu \mathrm{g} / \mathrm{mL}$ for $6 \mathrm{~h})$ and then treated with $5 \mathrm{nmol} / \mathrm{L}$ vitamin D or its vehicle. Analysis was performed $72 \mathrm{~h}$ post-shock. Values are folds of induction over control cultures (treated with bleomycin vehicle: PBS); veh.: vitamin $D$ vehicle. The results presented in the figures are means \pm SEM. Significance of the analysis is indicated as $* * *, P<0.001$. $\mathbf{b}$ Detection of VIM (vimentin) and ACTA2 (a-SMA) in myofibroblasts cell extracts. Cells were pretreated with $5 \mathrm{nmol} / \mathrm{L}$ vitamin D for $2 \mathrm{~h}$, subjected to a bleomycin shock $(12 \mu \mathrm{g} / \mathrm{mL}$ for $6 \mathrm{~h})$ and then treated with $5 \mathrm{nmol} / \mathrm{L}$ vitamin D or its vehicle. Cell extracts were obtained at $72 \mathrm{~h}$ post-shock. PBS is the bleomycin vehicle; veh.: vitamin D vehicle. TUBA1A (tubulin a) was used as loading control. KDa: kilodaltons. Bottom panel: densitometry analysis of bands; a.u: arbitrary units. c Representative micrographs of indirect immunofluorescence detection of ACTA2 (a-SMA fibers) and PTK2 (focal adhesion kinase), two markers of the profibrogenic activation. Cells were pretreated with $5 \mathrm{nmol} / \mathrm{L}$ vitamin $D$ for $2 \mathrm{~h}$, subjected to a bleomycin shock $(12 \mu \mathrm{g} / \mathrm{mL}$ for $6 \mathrm{~h})$ and then treated with $5 \mathrm{nmol} / \mathrm{L}$ vitamin D or its vehicle. Cells were processed for immunofluorescence $72 \mathrm{~h}$ post-shock. $\mathbf{d}$ Quantification of the immunofluorescence result (\% of activated fibroblasts showing clear expression of a-SMA fibers and PTK2)

bleomycin, the vitamin D treatment did not alter either the expression of DNA damage or the levels of cellular senescence. Moreover, the continuous exposure of cells to vitamin D in the absence of bleomycin did not affect their replication rates (Fig. 2b).

The increase in the levels of DNA damage induced by vitamin $D$ in the presence of bleomycin is not mediated by ROS

In the presence of $\mathrm{Fe}^{2+}$ and $\mathrm{O}_{2}$, bleomycin causes single-strand DNA breaks and DSBs. This occurs by chelation of the metal ion and the subsequent reaction with
$\mathrm{O}_{2}$, that leads to the production of DNA-cleaving superoxide $\left(\mathrm{O}_{2}{ }^{-}\right)$and hydroxide radicals (Bolzan and Bianchi 2018). We assessed whether vitamin D increase in DSBs in the presence of bleomycin could be the result of an increase in the levels of ROS. To do this, we evaluated both generic and mitochondrial ROS by flow cytometry and the probes DA-DCFH $\left(2^{\prime}, 7^{\prime}\right.$-dichlorodihydrofluorescein diacetate) and MitoSOX. DCFH-DA is a nonpolar dye, converted into the polar derivative DCFH by cellular esterases that are nonfluorescent but switched to highly fluorescent DCF when oxidized by intracellular ROS and other peroxides. MitoSOX is a 
fluorogenic dye that targets the mitochondria and is rapidly oxidized by superoxide but not by other ROS or reactive nitrogen species generating systems. In both type of cells, the treatment with bleomycin led to an elevation in ROS levels when the probe DCFH-DA was employed although fibroblasts seemed to be more resistant to bleomycin-induced ROS (Fig. 5a, c). However, this bleomycin-mediated induction of ROS did not modify the redox status of MitoSOX (Fig. 5b, d). In any case, vitamin D treatment increased the levels of ROS compared to its controls (Fig. 5a-d) according to previous reports supporting the notion that vitamin D has roles as antioxidant and antiaging (Berridge 2016; Datta Mitra et al. 2013; Jain and Micinski 2013; Valcheva et al. 2014). Next, we evaluated the cellular repair potential by irradiating A549 cells with $\gamma$-ray in the absence of bleomycin. Cells treated with vitamin D and subjected to 3Gy of $\gamma$ radiation showed no alterations in the cellular DSBs repair capabilities (Fig. 2c).
The increase in the levels of CDKN2A induced by vitamin $D$ in the presence of bleomycin is due to a posttranscriptional mechanism

The onset of cellular senescence observed in A549 treated with bleomycin and vitamin D cells was consistently associated with DNA damage and an increase in the expression levels of CDKN1A and CDKN2A. The augmented expression of these two senescence markers was not associated with an increase in the levels of mRNA (data not shown) suggesting a posttranscriptional regulatory mechanism established by vitamin $\mathrm{D}$. To confirm this hypothesis, we first confirmed the absence of transcriptional activity of the CDKN2A promoter upon the treatment with bleomycin and vitamin $\mathrm{D}$. In proliferating cells CDKN2A locus is maintained inactive by the continued presence of the histone methyltransferase EZH2-containing polycomb protein complex and it has been proposed that this is achieved by an enrichment of the repressive mark H3K273me (histone H3 trimethylated on Lys27) (Ito et al. 2018;
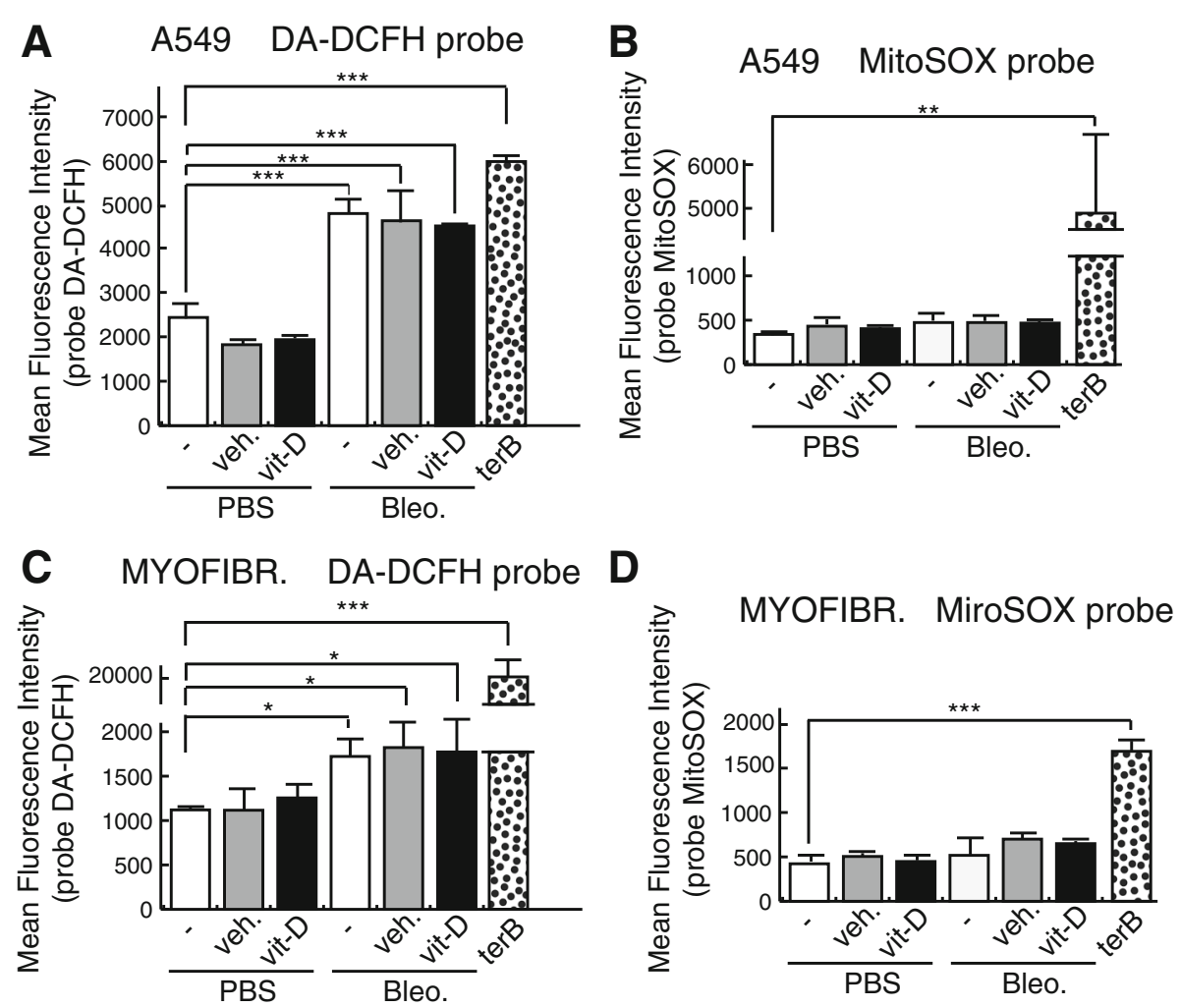

Fig. 5 ROS analyses with DA-DCFH and MitoSOX probes. a Analysis of reactive oxygen species (ROS) by flow citometry of A549 cells (panels a and $\mathbf{b}$ ) and myofibroblasts (panels $\mathbf{c}$ and $\mathbf{d}$ ). Cells were pretreated for $2 \mathrm{~h}$ with $5 \mathrm{nmol} / \mathrm{L}$ vitamin $\mathrm{D}$ and then treated for $24 \mathrm{~h}$ with bleomycin $(12,5 \mathrm{\mu g} / \mathrm{mL})$ and/or $5 \mathrm{nmol} / \mathrm{L}$ vitamin D. The cultures were then washed twice with Hank's balanced salt solution (HBSS) and incubated for $1 \mathrm{~h}$ with HBSS. After that, the cultures were incubated with DA-DCFH $(20 \mu \mathrm{M})$ in HBSS for $1 \mathrm{~h}$, washed and trypsinized. Trypsin was neutralized with HBSS-FBS $2 \%$ and the cells were collected and analyzed immediately by flow cytometry. The treatments with MitoSOX were carried-out as for the DA-DCFH probe. Cells were incubated for $1 \mathrm{~h}$ with $5 \mu \mathrm{M}$ MitoSOX in HBSS and then processed for flow cytometry. Controls for ROS induction employed in these experiments consisted of treatment for $1 \mathrm{~h}$ with $50 \mu \mathrm{M}$ terbutyl hydroperoxide (terB). The results presented in the graphs are means of the fluorescence intensity \pm SEM. ANOVA result $\mathbf{a}(P<0,001)$, ANOVA results $\mathbf{b}, \mathbf{c}$ and $\mathbf{d}(P<0,0001)$. Significance of the analysis post-test is indicated in the figure as ${ }^{*}, P<0.05 ;{ }^{*}, P<0.01$; and ${ }^{* *}, P<0.001$ 
Jacobs et al. 1999). In response to multiple stress and senescing signals the activity of EZH2 and the levels of H3K27-3me decreases giving rise to transcriptional activation. We therefore analyzed the presence of the repressive H3K27-3me mark and of chromatin activation (acetylated histone $\mathrm{H} 3$; H3-Ac) at the proximal CDKN2A promoter $(-277$ to +95$)$ by chromatin immunoprecipitation (Fig. 6a). CDKN2A promoter from cultured cells in the absence of bleomycin is enriched in H3K27-3me consistent with the absence of $C D K N 2 A$ expression. As expected, the treatment with bleomycin led to a drastic decrease in the repressive mark concomitant with the induction of senescence. However, in the presence of the damaging agent, neither the repressive mark nor the activation mark (H3-Ac) was increased with vitamin D (Fig. 6b). As a consequence, the promoter activity index determined as the ratios of $\mathrm{H} 3-\mathrm{Ac} /$ total $\mathrm{H} 3$ and $\mathrm{H} 3 \mathrm{~K} 27-3 \mathrm{me} /$ total $\mathrm{H} 3$ was maintained unaltered under the presence of bleomycin (Fig. 6c). Thus, the increase in the CDKN2A expression observed upon vitamin $\mathrm{D}$ treatment was not associated to transcriptional activation. We next evaluated the possibility that vitamin $\mathrm{D}$ treatment in the presence of bleomycin could increase the CDKN2A protein half-life. To do this, we analyzed CDKN2A expression at different times post-treatment with the inhibitor of protein synthesis cycloheximide. As shown in Fig. 6d, only in cells treated with vitamin $\mathrm{D}$ and bleomycin significant levels of CDKN2A protein could be detected after $24 \mathrm{~h}$ of the cycloheximide release.

\section{Vitamin D treatment aggravates bleomycin-induced lung fibrosis by increasing DNA damage}

In order to build an adequate model for IPF in mice we treated $\mathrm{C} 57 \mathrm{BL} / 6$ mice with two intraperitoneal injections of bleomycin $(100 \mathrm{mg} / \mathrm{Kg}$ b.d.) and after 11 days from the second injection we started the "therapeutic" treatment with vitamin D ( 5 ng/ g b.w.), or its vehicle, for 2 weeks. After that, at day 28, animals were sacrificed and examined. Mice were randomly divided into four groups: control, bleomycin, bleomycin+vehicle and bleomycin+vitamin D (3 experiments; $n=60$ ). We first validated vitamin $\mathrm{D}$ functionality by assessing the expression of liver Cyp24a1 by RT-qPCR. As shown in Fig. 7a, mice treated with bleomycin and vitamin D showed, as expected, the highest expression levels of this VDR target gene. We next analyzed the extension of fibrosis by the Masson's trichrome stain. We scored the levels of fibrosis as 0 (no fibrosis), 1 (low fibrosis), 2 (mild fibrosis) and 3 (severe fibrosis). We found that mice treated with bleomycin alone or with vitamin $\mathrm{D}$ vehicle consistently showed fibrosis levels $1-2$, characterized by interstitial fibrosis and fibrotic foci or patches along the pleura (subpleural fibrosis). However, mice treated with bleomycin and vitamin D showed the highest levels of fibrosis characterized by a severe architectural distortion and a striking subpleural fibrosis (Fig. 7b, c). Compared to controls mice, lungs from animals treated with bleomycin and vitamin $\mathrm{D}$ exhibited a characteristic whitish color probably due to the extension of fibrotic scarring (Fig. 7d). An additional striking feature of these mice was the weight loss during the progression of the disease. Mice treated with bleomycin and vitamin D exhibited the highest loses of weight concomitant with the exacerbation of lung pathology (right panel Fig. 7d). We also evaluated the expression of $C d k n 2 a$ by western-blot of tissue homogenates from representative experimental samples. $C d k n 2 a$ expression was significatively elevated in mice treated with bleomycin and vitamin D (Fig. 7e) compared to the rest of the groups. We next evaluated the expression of DNA damage by immunohistochemical stain of a marker or DNA damage and cellular senescence (Zambrano et al. 2014; Sedelnikova et al. 2004). The staining pattern of $\gamma \mathrm{H} 2 \mathrm{AFX}$ antibody consisted of either discrete DD foci corresponding to DSBs or massive nuclear accumulation of these DD foci showing a near pan-nuclear staining (Fig. 8a). Lung tissue from control mice showed low levels of DNA damage ( $<5 \%$ of the cells) consisted primarily in cells harboring a few DD foci. We found a homogeneous distribution of DNA damage at bronchiolar epithelia and alveolar cells throughout the lung (Fig. 8b). Bleomycin or bleomycin + vehicle mice showed higher levels of DNA damage (10-20\% of the cells) compared to control mice. This damage consisted of cells, mainly epithelial cells throughout the parenchyma, harboring several DD foci (Fig. 8c). The fibrosis extension in bleomycin + vitamin D treated animals was strikingly exacerbated exhibiting architectural distortion and subpleural fibrosis. This exacerbation correlated well with the expression of DNA damage. Damaged cells were more abundant in this group ( $>20 \%$ of the cells) than in the others, exhibiting nuclei with a large amount of DD in bronchiolar epithelium or at the alveolar fields (Fig. 9a, b). We also observed the typical abnormal re-epithelization of lesions found in IPF lungs with the presence of damaged cells (right picture, Fig. 9b). In addition, we found a differential distribution of damaged cells specifically at subpleural lesions. Epithelial cells in and around central and subpleural fibrotic foci harbored significant higher levels of DD foci compared with fibroblasts from the fibrotic lesions (Fig. 9c) in concordance with the in vitro fibroblasts resistance to a damage insult.

\section{Discussion}

We have analyzed the effects of the biological active form of vitamin D (calcitriol or 1 $\alpha$, 25-Dihydroxyvitamin $\mathrm{D}_{3}$ ) on representative cellular models for ATII cells and myofibroblasts, in terms of DNA damage, cellular 

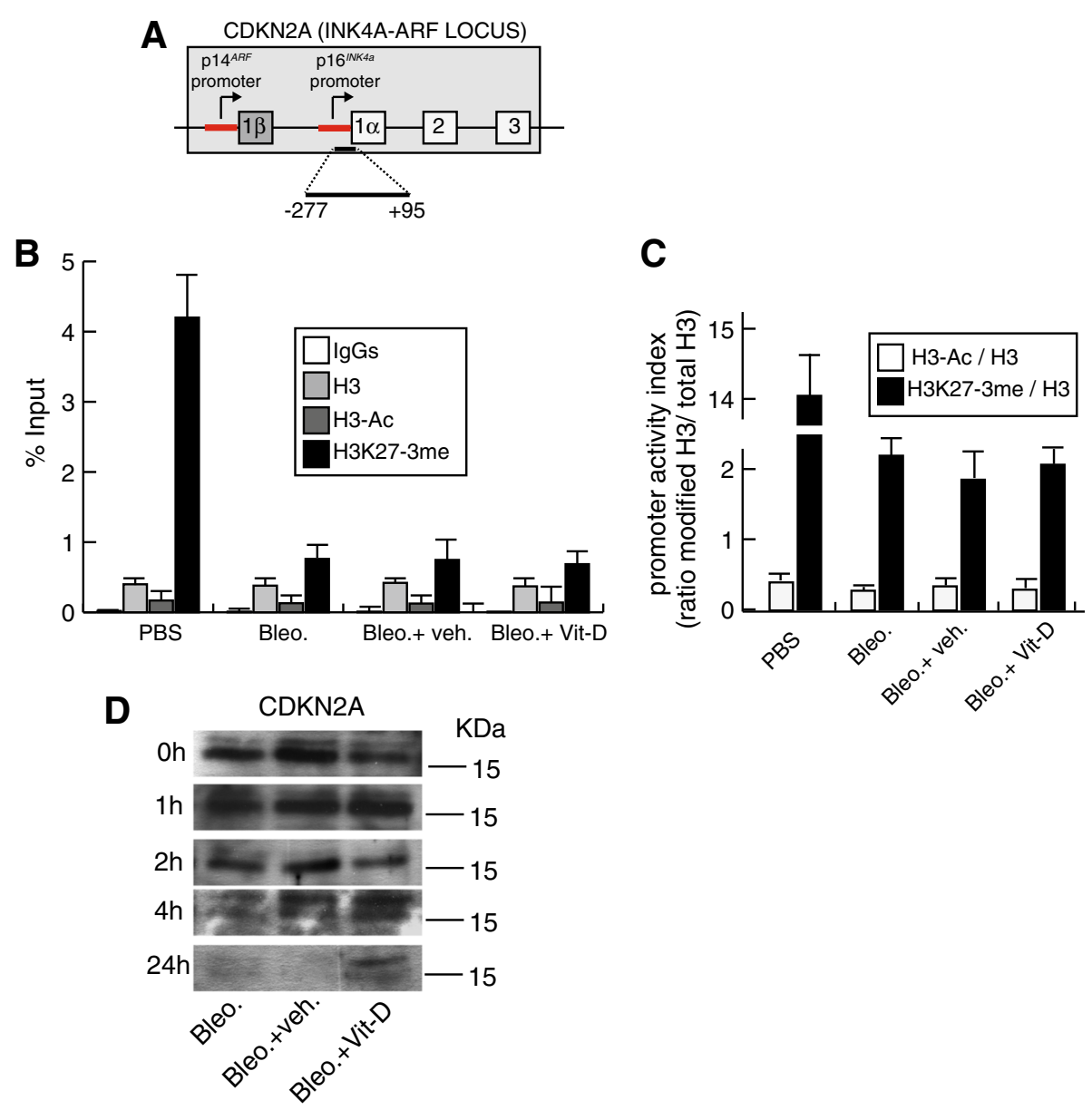

Fig. 6 Chromatin immunoprecipitation (ChIP) analysis of the CDKN2A $\left(\mathrm{p} 16^{I N K 4 a}\right)$ proximal promoter. a Diagram (not to scale) that illustrates the CDKN2A (INK4A-ARF) locus showing its exon/intron structure and the region analyzed corresponding to the proximal p16 ${ }^{\text {INK4a }}$ promoter (region 277 to +95 ). $\mathbf{b}$ ChIP result (\% of input) obtained with normal lgGs, and the antibodies directed against histone H3 (H3), acetylated histone H3 (H3-Ac) and Histone H3 trimethylated in Lys27 (H3K27-3me). Cells were pretreated with vitamin D or its vehicle, subjected to a bleomycin shock $(12 \mathrm{\mu g} / \mathrm{mL}$ for $6 \mathrm{~h})$ and then treated with $5 \mathrm{nmol} / \mathrm{L}$ vitamin D or its vehicle. Control cultures correspond to cells treated with bleomycin vehicle (PBS). c Promoter activity index as determined by the ratio of the \% input of modified histone H3/ \% input of total histone H3. Transcriptional activation is determined by the ratio $\mathrm{H} 3 \mathrm{Ac} / \mathrm{H} 3$ and repression by the corresponding ratio $\mathrm{H} 3 \mathrm{~K} 27-3 \mathrm{me} / \mathrm{H} 3$. The results presented in the graphs are means \pm SEM. ANOVA $P<0,0001$. d Determination of CDKN2A protein half-life. Cells were pretreated with $5 \mathrm{nmol} / \mathrm{L}$ vitamin $\mathrm{D}$ or its vehicle, subjected to a bleomycin shock $(12 \mu \mathrm{g} / \mathrm{mL}$ for $6 \mathrm{~h}$ ) and then treated with $5 \mathrm{nmol} / \mathrm{L}$ of vitamin $\mathrm{D}$ or vehicle for $24 \mathrm{~h}$. After that the cells were incubated with $100 \mu \mathrm{M}$ of cycloheximide for $24 \mathrm{~h}$. Detection of CDKN2A protein was performed in cell extracts of cultures released from cycloheximide inhibition at different times (from 0 to $24 \mathrm{~h}$ ). KDa: kilodaltons

senescence and fibrogenic activation. We have also assessed its potential antifibrotic therapeutic role in a mouse model of IPF based on intraperitoneal injections of bleomycin.

Our results indicate that low concentrations of bleomycin induce DSBs and cellular senescence more efficiently in A549 cells. In a previous report, Aoshiba et al. also described that immortalized A549 cells rapidly become senescent upon bleomycin treatment (Aoshiba et al. 2003). In the presence of a DNA damaging agent, the decrease in DNA damage expression as a consequence of DNA repair was lower in vitamin D treated cells than in the control ones, suggesting an alteration in the cellular
DSBs repair capabilities of A549 cells. This alteration would only take place in cells treated with bleomycin as cells treated with vitamin D in the absence of bleomycin do not exhibit more DNA damage than the controls and cells treated with vitamin D and subjected to 3Gy of $\gamma$ radiation showed no alterations in the cellular repair capacities of DSBs, at least, at the times assessed.

Vitamin D receptor is expressed in both cell types and fully functional as determined by the ligand induction of CYP24A1 expression. Neither the replication rates nor the ROS levels were increased in cells exposed to $5 \mathrm{nmol} / \mathrm{L}$ vitamin D. However, under the presence of a DNA damaging agent, vitamin $\mathrm{D}$ induced a posttranscriptional 


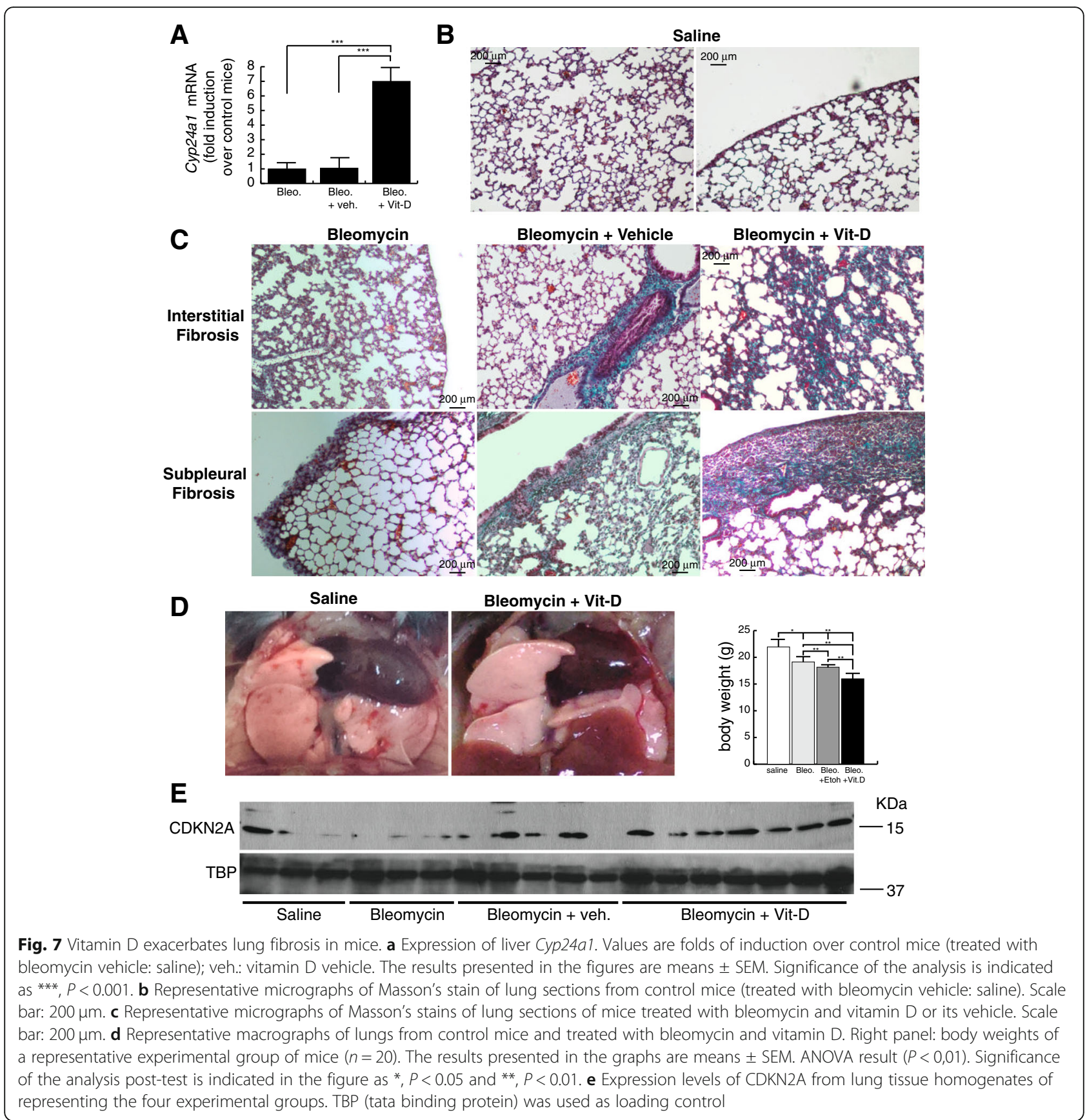

induction of $C D K N 2 A$ in A549 cells that together with the expression of DNA damage and the SA-ßgal activity contributed to the establishment of a canonical DNA damage-induced senescence program or premature senescence.

Bleomycin causes fibrotic lesions in C57BL/6 mice within a short period of time. It has been reported that the main histological hallmarks of IPF are present in bleomycin treated animals but it largely depends on the route of bleomycin administration (Chua et al. 2005). For instance, intratracheal instillation, the standard route of administration, produces a bronchiocentric fibrosis, whereas intravenous or intraperitoneal administration induces subpleural scarring similar to IPF (Chua et al. 2005). Bleomycin rapidly induces an acute inflammatory response lasting up to 8 days followed by the pure fibrotic response consisting of matrix deposition and lung architecture distortion out to 28 or 35 days (Moeller et al. 2008). Assuming this sequence of events, treatments during the first 7 days can be considered as preventive while treatments during the later stages after day 7-10 can be considered as therapeutic (Moeller et al. 2008). 
A

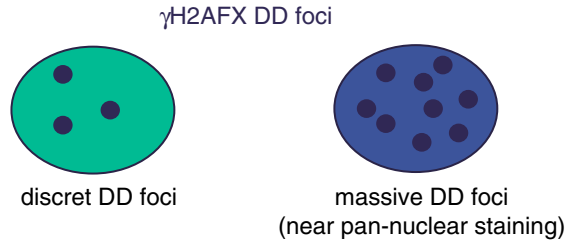

B

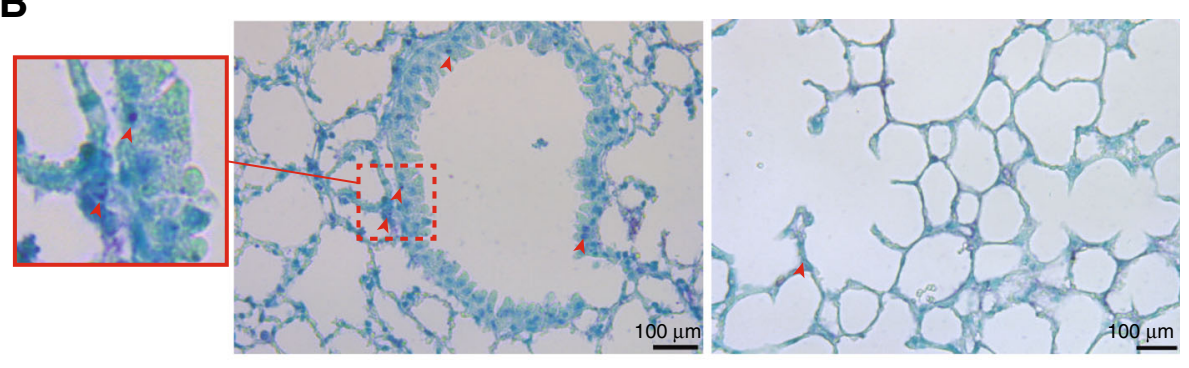

Bleomycin / Bleomycin + veh.

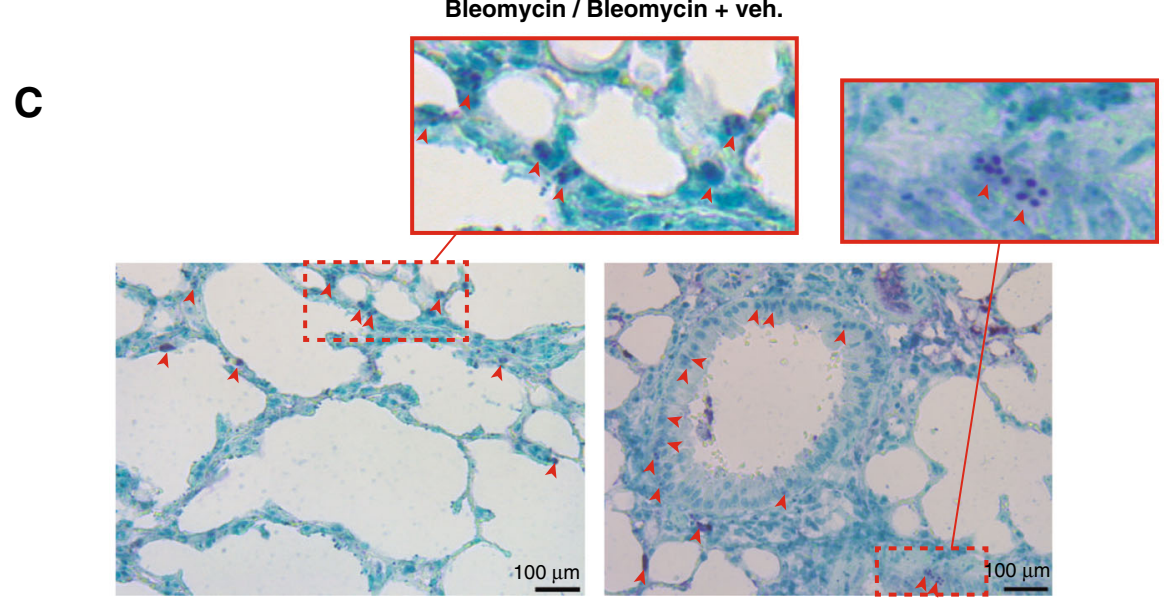

Fig. 8 DNA damage expression in lung tissue: expression of $\gamma H 2 A F X$ foci. a lllustration showing the staining pattern of $y H 2 A F X$. $y H 2 A F X$ is typically expressed as discrete foci or as a near pan-nuclear staining when the occurrence of DD foci is massive. $\mathbf{b}$ Expression of $\gamma \mathrm{H} 2 \mathrm{AFX}$ foci in representative sections of lung tissue from control mice (treated with saline). A magnification of an image of a respiratory bronchiole is depicted in the square on the left. Arrowheads signal some of the nuclei harboring DD foci containing YH2AFX distributed throughout the respiratory bronchiole or in alveolar fields (photograph on the right). c Expression of $\mathrm{yH} 2 \mathrm{AFX}$ foci in representative sections of lung tissue from mice treated with bleomycin or bleomycin + vehicle. Two magnifications of the images are depicted in the rectangles on the top. Arrowheads signal some of the nuclei harboring some DD foci containing $\mathrm{YH} 2 \mathrm{AFX}$ indicative of severe DNA damage. The magnitude and distribution of the damage observed was very similar in both groups. Scale bars: $100 \mu \mathrm{m}$

Some reports have indicated that supplementation of vitamin $\mathrm{D}$ ameliorated the fibrotic effects induced by bleomycin (Zhang et al. 2015; Tan et al. 2016; Zhang et al. 2013) but these effects were probably due to a preventive, anti-inflammatory treatment of vitamin D.

Bleomycin exposure of myofibroblasts however resulted in a fibrogenic activation that could be inhibited by the treatment with vitamin $\mathrm{D}$ as previously described. This differential response to DNA damage might be due to an inherent resistance of myofibroblasts to bleomycin ROS-induced DNA damage. A growing body of evidence indicates that epithelial fibroblast interactions play an essential role in the development of IPF (Noble 2008; Selman and Pardo 2006; Yanagi et al. 2015). Two types of AECs line up the alveolar wall, ATI and ATII cells. As result of the persistent tissue damage there is a net loss of alveolar epithelium with the subsequent integrity loss of the basement membrane. ATII cells are more resistant than ATI cells to damage and become activated to stimulate fibroblasts to produce extra cellular matrix components. Our results support this notion. Severely damaged cells with a phenotype compatible with ATII cells are lining the alveoli and in areas of abnormal re-epithelization. In addition, epithelial cells from bronchioles show clear signs of DNA damage in contrast to myofibroblasts from fibrotic foci such as those embedded at subpleural foci. These observations suggest that epithelial cells assimilate the bulk of the damage inflicted and trigger the activation and proliferation of fibroblasts. 
A

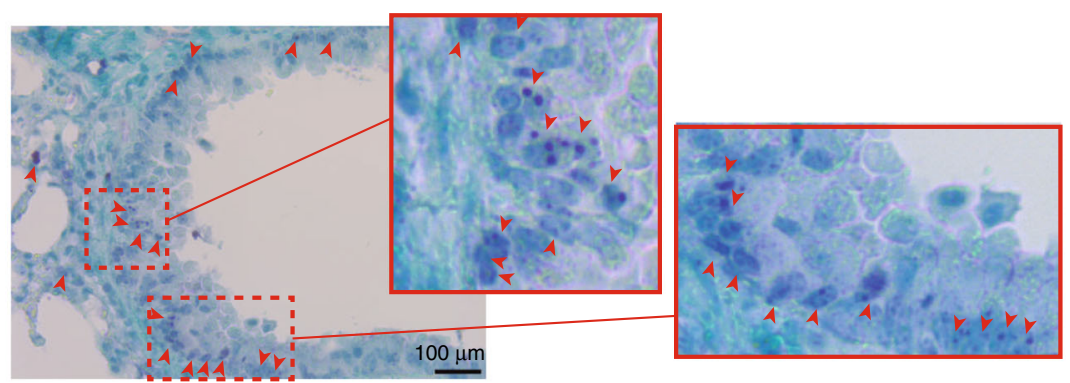

B

Bleomycin + Vit-D
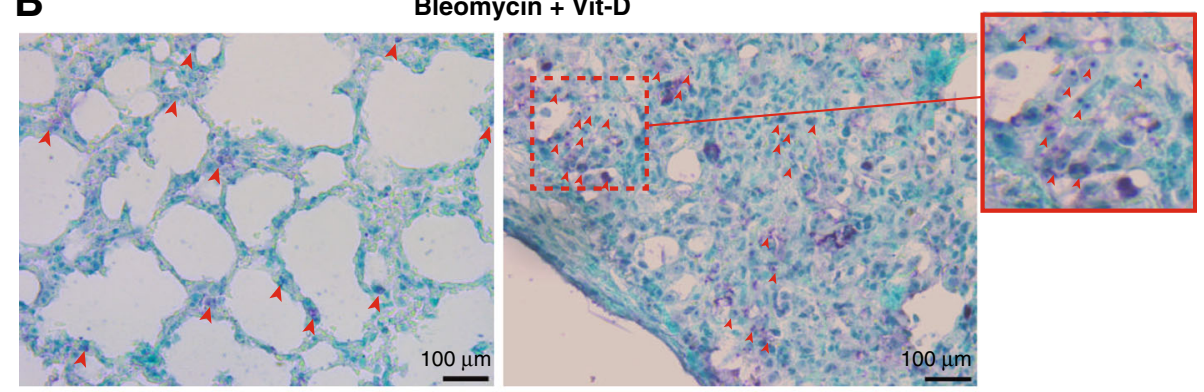

C

Bleomycin + Vit-D

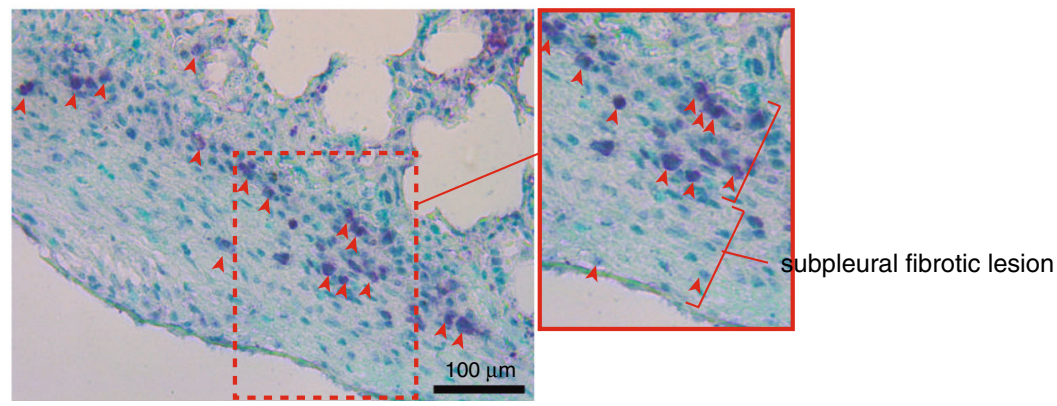

Fig. 9 Exacerbation of the DNA damage expression in lung tissue from mice treated with bleomycin and vitamin D. a Representative micrograph of a bronchiole surrounded by a fibrotic focus. Two magnifications of the image are depicted in the rectangles on the right. Arrowheads signal some of the multiple nuclei harboring DD foci containing YH2AFX indicative of severe DNA damage. $\mathbf{b}$ Representative micrographs of interstitial fibrosis (left) and of an area abnormally re-epithelialized (right) showing the expression of massive DNA damage specially in the epithelial component. c Representative image of a subpleural fibrotic lesion lined by an abnormally re-epithelialized area showing the presence of severe DNA damage especially in epithelial cells. Scale bars: $100 \mu \mathrm{m}$

These findings indicate vitamin $\mathrm{D}$ exacerbates the occurrence of fibrosis probably by increasing DNA damage primarily in epithelial cells of lungs subjected to a bleomycin insult. The presence of DNA damage and probably the onset of cellular senescence in ATII cells would compromise its function in the alveolar homeostasis maintenance. This abnormal alveolar regeneration has been observed in lungs from patients with IPF (Noble 2008; Selman and Pardo 2006; Kawanami et al. 1982).

Although some epidemiology studies suggest a potential relationship between vitamin D deficiency and advanced lung disease (Forli et al. 2004; Mascitelli et al. 2010), a systematic review of studies related to health outcome and vitamin D intakes shows no relationship between vitamin D supplement and the reduction in overall mortality of any cause (Chung et al. 2009; Manson et al. 2018; Newberry et al. 2014). Our study suggests that vitamin D supplementation could have an adverse effect in patients with signs of lung fibrosis.

\section{Conclusions}

Vitamin D exhibited an unexpected detrimental activity in the presence of a DNA damaging agent. This activity is probably due to a suboptimal capability repair of DSBs associated to the establishment of a senescence phenotype of ATII cells and to the exacerbation of the lung pathology induced by bleomycin. The detrimental effects of vitamin D in the presence of a DNA damaging agent might preclude its use as an antifibrogenic agent in pulmonary fibrosis characterized by DNA damage 
occurrence and cellular senescence such as the idiopathic pulmonary fibrosis.

\section{Abbreviations}

ACTA2: Actin, alpha 2, smooth muscle, aorta (a-smooth muscle actin, a-SMA); ACTB: Actin beta; AEC: Alveolar epithelial cell; ANOVA: Analysis of variance; ATI: Alveolar type I cell; ATIl: Alveolar type II cell; b.w.: Body weight; BSA: Bovine serum albumin; CDKN1A: Cyclin dependent kinase inhibitor 1A (p21); CDKN2A: Cyclin dependent kinase inhibitor 2A (p16);

COL1A1: Collagen type I alpha 1 chain; COL3A1: Collagen type III alpha 1 chain; CYP24A1: Cytochrome P450 family 24 subfamily A member 1; DD: DNA damage; DSBs: DNA double-strand breaks; FBS: Fetal bovine serum; H2AFX: H2A histone family member X; IgGs: Immunoglobulin G; MW6: 6-well plates; O/N: Over night; PBS: Phosphate buffered saline; PTK2: Focal adhesion kinase (FAK); ROS: Reactive oxygen species; SA- $\beta$ gal: Senescence associated $\beta$-galactosidase activity; SDS: Sodium dodecyl sulfate; SEM: Standard error of the mean; TGFB1: Transforming growth factor beta 1; TP53BP1: Tumor protein p53 binding protein 1; TUBA1A: Tubulin alpha 1a; VDR: Vitamin D receptor; VIM: Vimentin; $\mu$ m: Micrometer

\section{Acknowledgments}

We thank the core facilities of the Functional Unit for Research into Chronic Diseases (UFIEC-ISCIII) for technical help.

\section{Funding}

This work was supported by Grants MPY-1038/14 and MPY-1146/16 from Institute of Health Carlos III (ISCIII) to Alberto Zambrano and SAF-2015-71140$R$ from Ministry of Economy and Competitiveness (MINECO) to Isabel Liste.

\section{Availability of data and materials}

Please contact authors for data requests.

\section{Authors' contributions}

TG and EM-L performed, designed experiments and analyzed data. JM and RG$M$ performed experiments and analyzed data. MJF-A designed experiments and analyzed data, IL performed, designed experiments and analyzed data. AZ performed, designed experiments, analyzed data, wrote paper and conceived the project. All authors read and approved the final manuscript.

\section{Ethics approval}

The experiments involving animals were approved by the Committee of Bioethics and Animal Welfare of the Instituto de Salud Carlos III and Community of Madrid (file reference: PROEX-312). Protocols used followed the guidelines for animal protection reported by the Spanish national law RD 53/2013.

\section{Consent for publication}

The authors give their full permission for the publication and reproduction of the content of this article.

\section{Competing interests}

The authors declare that they have no competing interests.

\section{Publisher's Note}

Springer Nature remains neutral with regard to jurisdictional claims in published maps and institutional affiliations.

\section{Author details}

${ }^{1}$ Functional Unit for Research into Chronic Diseases, Institute of Health Carlos III, Ctra. Majadahonda-Pozuelo Km 2, 28220 Madrid, Spain. ${ }^{2}$ Hospital Clinico San Carlos, Madrid, Spain.

Received: 25 September 2018 Accepted: 3 December 2018 Published online: 19 December 2018

\section{References}

Aoshiba K, Tsuji T, Kameyama S, Itoh M, Semba S, Yamaguchi K, et al. Senescence-associated secretory phenotype in a mouse model of bleomycin-induced lung injury. Exp Toxicol Pathol. 2013;65(7-8):1053-62.

Aoshiba K, Tsuji T, Nagai A. Bleomycin induces cellular senescence in alveolar epithelial cells. Eur Respir J. 2003;22(3):436-43.
Berridge MJ. Vitamin D, reactive oxygen species and calcium signalling in ageing and disease. Philos Trans R Soc Lond B Biol Sci. 2016;371(1700).

Bolzan AD, Bianchi MS. DNA and chromosome damage induced by bleomycin in mammalian cells: an update. Mutat Res. 2018;775:51-62.

Chilosi M, Carloni A, Rossi A, Poletti V. Premature lung aging and cellular senescence in the pathogenesis of idiopathic pulmonary fibrosis and COPD/ emphysema. Transl Res. 2013;162(3):156-73.

Chua F, Gauldie J, Laurent GJ. Pulmonary fibrosis: searching for model answers. Am J Respir Cell Mol Biol. 2005;33(1):9-13.

Chung M, Balk EM, Brendel M, Ip S, Lau J, Lee J, et al. Vitamin D and calcium: a systematic review of health outcomes. Evid Rep Technol Assess (Full Rep). 2009;(183):1-420.

Datta Mitra A, Raychaudhuri SP, Abria CJ, Mitra A, Wright R, Ray R, et al. 1alpha,25Dihydroxyvitamin-D3-3-bromoacetate regulates AKT/mTOR signaling cascades: a therapeutic agent for psoriasis. J Invest Dermatol. 2013;133(6):1556-64.

Dimri GP, Lee X, Basile G, Acosta M, Scott G, Roskelley C, et al. A biomarker that identifies senescent human cells in culture and in aging skin in vivo. Proc Natl Acad Sci. 1995; 92(20):9363-67.

Ding N, Yu RT, Subramaniam N, Sherman MH, Wilson C, Rao R, et al. A vitamin D receptor/SMAD genomic circuit gates hepatic fibrotic response. Cell. 2013; 153(3):601-13.

Finklea JD, Grossmann RE, Tangpricha V. Vitamin D and chronic lung disease: a review of molecular mechanisms and clinical studies. Adv Nutr. 2011;2(3):244-53.

Forli L, Halse J, Haug E, Bjortuft O, Vatn M, Kofstad J, et al. Vitamin D deficiency, bone mineral density and weight in patients with advanced pulmonary disease. J Intern Med. 2004;256(1):56-62.

Haring M, Offermann S, Danker T, Horst I, Peterhansel C, Stam M. Chromatin immunoprecipitation: optimization, quantitative analysis and data normalization. Plant Methods. 2007;3:11.

Hecker L, Logsdon NJ, Kurundkar D, Kurundkar A, Bernard K, Hock T, et al. Reversal of persistent fibrosis in aging by targeting Nox4-Nrf2 redox imbalance. Sci Transl Med. 2014;6(231):231 ra47.

Ito I, Waku T, Aoki M, Abe R, Nagai Y, Watanabe T, et al. A nonclassical vitamin D receptor pathway suppresses renal fibrosis. J Clin Invest. 2013;123(11):4579-94.

Ito T, Teo W, Evans SA, Neretti N, Sedivy JM. Regulation of cellular senescence by Polycomb chromatin modifiers through distinct DNA damage- and histone methylation-dependent pathways. Cell Rep. 2018;22(13):3480-92.

Jacobs JJ, Kieboom K, Marino S, DePinho RA, van Lohuizen M. The oncogene and Polycomb-group gene bmi-1 regulates cell proliferation and senescence through the ink4a locus. Nature. 1999:397(6715):164-8.

Jain SK, Micinski D. Vitamin D upregulates glutamate cysteine ligase and glutathione reductase, and GSH formation, and decreases ROS and MCP-1 and IL-8 secretion in high-glucose exposed U937 monocytes. Biochem Biophys Res Commun. 2013;437(1):7-11.

Kawanami O, Ferrans VJ, Crystal RG. Structure of alveolar epithelial cells in patients with fibrotic lung disorders. Lab Investig. 1982;46(1):39-53.

King TE Jr, Pardo A, Selman M. Idiopathic pulmonary fibrosis. Lancet. 2011; 378(9807):1949-61.

Kuwano K, Araya J, Hara H, Minagawa S, Takasaka N, Ito S, et al. Cellular senescence and autophagy in the pathogenesis of chronic obstructive pulmonary disease (COPD) and idiopathic pulmonary fibrosis (IPF). Respir Investig. 2016;54(6):397-406

Kuwano K, Kunitake R, Kawasaki M, Nomoto Y, Hagimoto N, Nakanishi Y, et al. P21Waf1/Cip1/Sdi1 and p53 expression in association with DNA strand breaks in idiopathic pulmonary fibrosis. Am J Respir Crit Care Med. 1996;154(2 Pt 1):477-83.

Lagares D, Busnadiego O, Garcia-Fernandez RA, Kapoor M, Liu S, Carter DE, et al. Inhibition of focal adhesion kinase prevents experimental lung fibrosis and myofibroblast formation. Arthritis Rheum. 2012;64(5):1653-64.

Lee YC, Hung SY, Liou HH, Lin TM, Tsai CH, Lin SH, et al. Vitamin D can ameliorate chlorhexidine gluconate-induced peritoneal fibrosis and functional deterioration through the inhibition of epithelial-to-mesenchymal transition of mesothelial cells. Biomed Res Int. 2015;2015:595030.

Lv XX, Wang XX, Li K, Wang ZY, Li Z, Lv Q, et al. Rupatadine protects against pulmonary fibrosis by attenuating PAF-mediated senescence in rodents. PLoS One. 2013;8(7):e68631.

Magro-Lopez E, Guijarro T, Martinez I, Martin-Vicente M, Liste I, Zambrano A. A two-dimensional human minilung system (Model) for respiratory syncytial virus infections. Viruses. 2017:9(12):379.

Manson JE, Cook NR, Lee IM, Christen W, Bassuk SS, Mora S, et al. Vitamin D Supplements and Prevention of Cancer and Cardiovascular Disease. N Engl J Med. 2018. https://doi.org/10.1056/NEJMoa1809944. 
Mascitelli L, Pezzetta F, Goldstein MR. Vitamin D and mortality from pulmonary fibrosis. Chest. 2010;137(2):495-6.

Meredith A, Boroomand S, Carthy J, Luo Z, McManus B. 1,25 Dihydroxyvitamin D3 inhibits TGFbeta1-mediated primary human cardiac Myofibroblast activation. PLoS One. 2015;10(6):e0128655.

Moeller A, Ask K, Warburton D, Gauldie J, Kolb M. The bleomycin animal model: a useful tool to investigate treatment options for idiopathic pulmonary fibrosis? Int J Biochem Cell Biol. 2008;40(3):362-82.

Newberry SJ, Chung M, Shekelle PG, Booth MS, Liu JL, Maher AR, et al. Vitamin D and Calcium: A Systematic Review of Health Outcomes (Update). Evid Rep Technol Assess (Full Rep). 2014;(217):1-929.

Noble PW. Epithelial fibroblast triggering and interactions in pulmonary fibrosis. Eur Respir Rev. 2008;17(109):123-9.

Pike JW, Christakos S. Biology and mechanisms of action of the Vitamin D hormone. Endocrinol Metab Clin N Am. 2017:46(4):815-43.

Schafer MJ, White TA, lijima K, Haak AJ, Ligresti G, Atkinson EJ, et al. Cellular senescence mediates fibrotic pulmonary disease. Nat Commun. 2017;8:14532.

Schapochnik A, da Silva MR, Leal MP, Esteves J, Hebeda CB, Sandri S, et al. Vitamin $\mathrm{D}$ treatment abrogates the inflammatory response in paraquatinduced lung fibrosis. Toxicol Appl Pharmacol. 2018;355:60-7.

Sedelnikova OA, Horikawa I, Zimonjic DB, Popescu NC, Bonner WM, Barrett JC. Senescing human cells and ageing mice accumulate DNA lesions with unrepairable double-strand breaks. Nat Cell Biol. 2004;6(2):168-70.

Selman M, Pardo A. Role of epithelial cells in idiopathic pulmonary fibrosis: from innocent targets to serial killers. Proc Am Thorac Soc. 2006;3(4):364-72.

Shivshankar P, Brampton C, Miyasato S, Kasper M, Thannickal VJ, Le Saux CJ. Caveolin-1 deficiency protects from pulmonary fibrosis by modulating epithelial cell senescence in mice. Am J Respir Cell Mol Biol. 2012;47(1):28-36.

Tan ZX, Chen YH, Xu S, Qin HY, Zhang C, Zhao H, et al. Calcitriol inhibits bleomycin-induced early pulmonary inflammatory response and epithelialmesenchymal transition in mice. Toxicol Lett. 2016;240(1):161-71.

Valcheva P, Cardus A, Panizo S, Parisi E, Bozic M, Lopez Novoa JM, et al. Lack of vitamin $D$ receptor causes stress-induced premature senescence in vascular smooth muscle cells through enhanced local angiotensin-II signals. Atherosclerosis. 2014;235(2):247-55.

Wang Z, Zhang H, Sun X, Ren L. The protective role of vitamin D3 in a murine model of asthma via the suppression of TGF-beta/Smad signaling and activation of the Nrf2/HO-1 pathway. Mol Med Rep. 2016;14(3):2389-96.

Yanagi S, Tsubouchi H, Miura A, Matsumoto N, Nakazato M. Breakdown of epithelial barrier integrity and overdrive activation of alveolar epithelial cells in the pathogenesis of acute respiratory distress syndrome and lung fibrosis. Biomed Res Int. 2015;2015:573210.

Zambrano A, Garcia-Carpizo V, Gallardo ME, Villamuera R, Gomez-Ferreria MA, Pascual A, et al. The thyroid hormone receptor beta induces DNA damage and premature senescence. J Cell Biol. 2014;204(1):129-46.

Zhang Z, Yu X, Fang X, Liang A, Yu Z, Gu P, et al. Preventive effects of vitamin D treatment on bleomycin-induced pulmonary fibrosis. Sci Rep. 2015;5:17638.

Zhang ZM, Gu P, Yi XH, Fang X, Zeng Y, Zhang SX, et al. Effects of 1, $25(\mathrm{OH}) 2 \mathrm{D} 3$ on bleomycin-induced pulmonary fibrosis in mice. Zhonghua Jie He He Hu Xi Za Zhi. 2013:36(11):814-20.

Ready to submit your research? Choose BMC and benefit from:

- fast, convenient online submission

- thorough peer review by experienced researchers in your field

- rapid publication on acceptance

- support for research data, including large and complex data types

- gold Open Access which fosters wider collaboration and increased citations

- maximum visibility for your research: over $100 \mathrm{M}$ website views per year

At BMC, research is always in progress.

Learn more biomedcentral.com/submissions 